\title{
Tobacco Product Use and Associated Factors Among Middle and High School Students - United States, 2019
}




\section{CONTENTS}

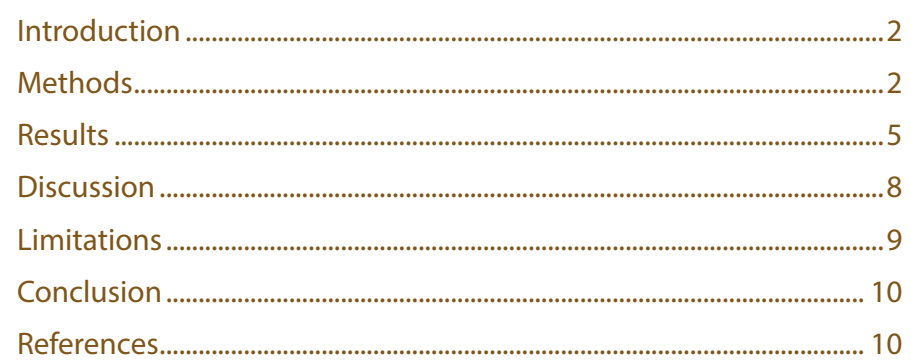

The MMWR series of publications is published by the Center for Surveillance, Epidemiology, and Laboratory Services, Centers for Disease Control and Prevention (CDC), U.S. Department of Health and Human Services, Atlanta, GA 30329-4027.

Suggested citation: [Author names; first three, then et al., if more than six.] [Title]. MMWR Surveill Summ 2019;68(No. SS-\#):[inclusive page numbers].

\section{Centers for Disease Control and Prevention \\ Robert R. Redfield, MD, Director}

Anne Schuchat, MD, Principal Deputy Director

Chesley L. Richards, MD, MPH, Deputy Director for Public Health Science and Surveillance

Rebecca Bunnell, PhD, MEd, Director, Office of Science

Barbara Ellis, PhD, MS, Acting Director, Office of Science Quality, Office of Science

Michael F. Iademarco, MD, MPH, Director, Center for Surveillance, Epidemiology, and Laboratory Services

\section{MMWR Editorial and Production Staff (Serials)}

Charlotte K. Kent, PhD, MPH, Editor in Chief Christine G. Casey, MD, Editor

Mary Dott, MD, MPH, Online Editor

Terisa F. Rutledge, Managing Editor

David C. Johnson, Lead Technical Writer-Editor Marella Meadows, Project Editor

Ileana Arias, $\mathrm{PhD}$

Jay C. Butler, MD

Matthew L. Boulton, MD, MPH

Virginia A. Caine, MD

Katherine Lyon Daniel, PhD
MMWR Editorial Board

Timothy F. Jones, MD, Chairman

Jonathan E. Fielding, MD, MPH, MBA

David W. Fleming, MD

William E. Halperin, MD, DrPH, MPH

Jewel Mullen, MD, MPH, MPA

Jeff Niederdeppe, PhD

Patricia Quinlisk, MD, MPH
Martha F. Boyd, Lead Visual Information Specialist Maureen A. Leahy, Julia C. Martinroe, Stephen R. Spriggs, Tong Yang, Visual Information Specialists

Quang M. Doan, MBA, Phyllis H. King, Terraye M. Starr, Moua Yang, Information Technology Specialists

Stephen C. Redd, MD

Patrick L. Remington, MD, MPH

Carlos Roig, MS, MA

William Schaffner, MD

Morgan Bobb Swanson, BS 


\title{
Tobacco Product Use and Associated Factors Among Middle and High School Students — United States, 2019
}

Teresa W. Wang, $\mathrm{PhD}^{1}$; Andrea S. Gentzke, $\mathrm{PhD}^{1}$; MeLisa R. Creamer, $\mathrm{PhD}^{1}$; Karen A. Cullen, $\mathrm{PhD}^{2}$; Enver Holder-Hayes, $\mathrm{MPH}^{2}$; Michael D. Sawdey, $\mathrm{PhD}^{2}$; Gabriella M. Anic, $\mathrm{PhD}^{2}$; David B. Portnoy, $\mathrm{PhD}^{2}$; Sean Hu, $\mathrm{DrPH}^{1}$; David M. Homa, $\mathrm{PhD}^{1}$; Ahmed Jamal, MBBS${ }^{1}$; Linda J. Neff, $\mathrm{PhD}^{1}$

${ }^{1}$ Office on Smoking and Health, National Center for Chronic Disease Prevention and Health Promotion, CDC

${ }^{2}$ Center for Tobacco Products, Food and Drug Administration, Silver Spring, Maryland

\begin{abstract}
Problem/Condition: Tobacco use is the leading cause of preventable disease, disability, and death in the United States. Most tobacco product use begins during adolescence. In recent years, tobacco products have evolved to include various smoked, smokeless, and electronic products.

Period Covered: 2019.

Description of System: The National Youth Tobacco Survey (NYTS) is an annual, cross-sectional, school-based, self-administered survey of U.S. middle school (grades 6-8) and high school (grades 9-12) students. A three-stage cluster sampling procedure is used to generate a nationally representative sample of U.S. students attending public and private schools. NYTS is the only nationally representative survey of U.S. middle and high school students that focuses exclusively on tobacco product use patterns and associated factors. NYTS is designed to provide national data on tobacco product use and has been conducted periodically during 1999-2009 and annually since 2011. Data from NYTS are used to support the design, implementation, and evaluation of comprehensive tobacco use prevention and control programs and to inform tobacco regulatory activities. Since its inception in 1999 through 2018, NYTS had been conducted via paper and pencil questionnaires. In 2019, NYTS for the first time was administered in schools using electronic data collection methods. CDC's Office on Smoking and Health, in collaboration with the U.S. Food and Drug Administration's (FDA's) Center for Tobacco Products, analyzed data from the 2019 NYTS to assess tobacco product use patterns and associated factors among U.S. middle and high school students. Overall, 19,018 questionnaires were completed and weighted to represent approximately 27.0 million students. On the basis of self-reported grade level, this included 8,837 middle school questionnaires (11.9 million students) and 10,097 high school questionnaires (15.0 million students); 84 questionnaires with missing information on grade level were excluded from school-level analyses.
\end{abstract}

Results: In 2019, an estimated 53.3\% of high school students (8.0 million) and 24.3\% of middle school students (2.9 million) reported having ever tried a tobacco product. Current (past 30-day) use of a tobacco product (i.e., electronic cigarettes [e-cigarettes], cigarettes, cigars, smokeless tobacco, hookahs, pipe tobacco, and bidis [small brown cigarettes wrapped in a leaf]) was reported by $31.2 \%$ of high school students (4.7 million) and $12.5 \%$ of middle school students (1.5 million). E-cigarettes were the most commonly cited tobacco product currently used by $27.5 \%$ of high school students ( 4.1 million) and $10.5 \%$ of middle school students (1.2 million), followed in order by cigars, cigarettes, smokeless tobacco, hookahs, and pipe tobacco. Tobacco product use also varied by sex and race/ethnicity. Among current users of each tobacco product, the prevalence of frequent tobacco product use (on $\geq 20$ days of the preceding 30 days) ranged from $16.8 \%$ of cigar smokers to $34.1 \%$ of smokeless tobacco product users. Among current users of each individual tobacco product, e-cigarettes were the most commonly used flavored tobacco product ( $68.8 \%$ of current e-cigarette users). Among students who reported ever having tried e-cigarettes, the three most commonly selected reasons for use were "I was curious about them" (55.3\%), "friend or family member used them" (30.8\%), and "they are available in flavors, such as mint, candy, fruit, or chocolate" (22.4\%). Among never users of each individual tobacco product, curiosity and susceptibility (a construct that can help to identify future tobacco product experimentation or use) was highest for e-cigarettes (39.1\% and 45.0\%, respectively) and cigarettes $(37.0 \%$ and $45.9 \%$, respectively). Overall, $86.3 \%$ of students who reported contact with an assessed potential source of tobacco product advertisements or promotions (going to a convenience store, supermarket, or gas station; using the Internet; watching television or streaming services or going to the movies; or reading

Corresponding author: Teresa W. Wang, PhD, Office on Smoking and Health, National Center for Chronic Disease Prevention and Health Promotion, CDC. Telephone: 770-488-5493; E-mail twwang@cdc.gov. newspapers or magazines) reported exposure to marketing for any tobacco product; $69.3 \%$ reported exposure to e-cigarette marketing and $81.7 \%$ reported exposure to marketing for cigarettes or other tobacco products. Among all students, perceiving no harm or little 
harm from intermittent tobacco product use (use on some days but not every day) was $28.2 \%$ for e-cigarettes, $16.4 \%$ for hookahs, $11.5 \%$ for smokeless tobacco products, and $9.5 \%$ for cigarettes. Among current users of any tobacco product, $24.7 \%$ reported experiencing cravings to use tobacco products during the past 30 days and $13.7 \%$ reported wanting to use a tobacco product within 30 minutes of waking. Moreover, $57.8 \%$ of current tobacco product users reported they were seriously thinking about quitting the use of all tobacco products and $57.5 \%$ reported they had stopped using all tobacco products for $\geq 1$ day because they were trying to quit.

Interpretation: In 2019, approximately one in four youths (23.0\%) had used a tobacco product during the past 30 days. By school level, this represented approximately three in 10 high school students $(31.2 \%)$ and approximately one in eight middle school students (12.5\%). Since 2014, e-cigarettes have been the most commonly used tobacco product among youths. Importantly, more than half of current youth tobacco product users reported seriously thinking about quitting all tobacco products in 2019. However, established factors of use and initiation, including the availability of flavors, exposure to tobacco product marketing, curiosity and susceptibility, and misperceptions about harm from tobacco product use, remained prevalent in 2019 and continue to promote tobacco product use among youths.

Public Health Action: The continued monitoring of all forms of youth tobacco product use and associated factors through surveillance efforts including NYTS is important to the development of public health policy and action at national, state, and community levels. Everyone, including public health professionals, health care providers, policymakers, educators, parents, and others who influence youths, can help protect youths from the harms of all tobacco products. In addition, the comprehensive and sustained implementation of evidence-based tobacco control strategies, combined with FDA's regulation of tobacco products, is important for reducing all forms of tobacco product use among U.S. youths.

\section{Introduction}

Tobacco product use is the leading cause of preventable disease, disability, and death in the United States (1). Preventing tobacco product use among youths is critical to decreasing morbidity and mortality because nearly all tobacco product use begins during youth or young adulthood; approximately nine in 10 adult cigarette smokers start before age 18 years (1-3). In recent years, tobacco products have evolved to include various smoked, smokeless, and electronic products.

The National Youth Tobacco Survey (NYTS), conducted periodically during 1999-2009 and annually since 2011, provides national data on estimates of tobacco product use to support the design, implementation, and evaluation of comprehensive youth tobacco prevention and control programs and to inform tobacco regulatory activities in the United States (4). NYTS is the only nationally representative survey of U.S. middle school (grades 6-8) and high school (grades 9-12) students that focuses exclusively on tobacco product use and associated factors.

This report uses findings from the 2019 NYTS to describe the prevalence of youth tobacco product use and selected associated factors, including flavored tobacco product use, reasons for use, exposure to tobacco product marketing, curiosity and susceptibility, harm perceptions, urges to use tobacco products, and quitting behaviors. These findings can be used by public health professionals, health care providers, policymakers, educators, parents, and others who influence youths to prevent and reduce tobacco product use among U.S. youths.

\section{Methods}

\section{National Youth Tobacco Survey Sampling Procedures}

NYTS is a cross-sectional, school-based, self-administered survey of U.S. middle and high school students (4). The 2019 NYTS sampling frame consisted of all regular public and private schools with students enrolled in grades 6-12 in the 50 U.S. states and the District of Columbia. The sampling frame comprised data obtained from Market Data Retrieval (5) and the National Center for Education Statistics (6,7). Alternative schools, special education schools, U.S. Department of Defenseoperated schools, Bureau of Indian Affairs schools, vocational schools, and schools with a combined total of $<40$ students in grades 6-12 were excluded. Participation in NYTS was voluntary at both the school and student levels; parental consent and student assent were required for NYTS participation.

The 2019 NYTS used a stratified, three-stage cluster sample design. Sampling procedures were probabilistic and conducted without replacement at all stages. Primary sampling units (PSUs), defined as individual counties, portions of a county, or groups of counties, were randomly selected within each stratum. PSUs were organized into 16 strata on the basis of urban or rural location and racial or ethnic group. Secondary sampling units, defined as schools or linked schools, were randomly selected within each PSU. The third and final sampling stage consisted of randomly selected classes. All students in the selected classes were eligible to participate in the survey; however, students who were unable to complete the questionnaire without special assistance were excluded. 


\section{Data Collection and Processing}

Since its inception in 1999, NYTS had been conducted via paper and pencil questionnaires. In 2019, NYTS for the first time was administered in schools using electronic data collection methods. Participants were provided with a tablet computer (Samsung Galaxy Tab A) to complete the survey. Data were collected offline using a programmed survey application, and a single class period of approximately 35-45 minutes was allotted to complete the survey. Survey administrators later established secure WiFi connections to synchronize all locally stored tablet data to a central repository via encrypted transmissions. Absent students and whole classes unavailable on the day of survey administration could participate in make-up surveys using a web-based version of the questionnaire programmed to mimic the tablet-based application. The 2019 NYTS was reviewed and approved by the Office of Management and Budget, the contracted data collectors' institutional review board (IRB), and CDC's IRB.

The 2019 questionnaire contained 104 questions covering demographic information, tobacco product use, knowledge and attitudes about tobacco products, protobacco and antitobacco media and advertising, access to tobacco products, nicotine dependence, cessation attempts, secondhand smoke and secondhand aerosol exposure, harm perceptions, exposure to tobacco product health warnings, and other tobaccorelated topics. Tobacco product images and descriptions were displayed in a preamble before each tobacco product-specific section. Respondents did not answer all questions because of questionnaire skip patterns (e.g., nonusers of e-cigarettes skipped questions specific to current use of e-cigarettes) and the voluntary nature of the survey.

Survey administration occurred from February 15, 2019, to May 24, 2019. The final sample consisted of 325 schools, of which 251 participated (school response rate: 77.2\%). A total of 19,018 student questionnaires were completed (17,197 tablet based and 1,821 web based) out of a sample of 22,153 students (student response rate: $85.8 \%$ ). The overall response rate, defined as the product of the school-level and student-level response rates, was $66.3 \%$. After exclusion of outliers, the average survey completion time was approximately 12.5 minutes. A weighting factor was applied to each student record to adjust for nonresponse and for varying probabilities of selection. Weights were adjusted to ensure that the weighted proportions of students in each grade matched national population proportions. Additional information on the NYTS sampling design, recruitment procedures, and data weighting is available (https://www.cdc.gov/tobacco/data_statistics/surveys/ nyts/index.htm).

\section{Analyses}

Statistical analyses were conducted using SAS-callable SUDAAN software (version 11.0.1; RTI International) to account for the complex sampling design (8). Weighted prevalence estimates and 95\% confidence intervals were computed for all measures, and population totals were estimated from probability weights. Overall, 19,018 questionnaires were weighted to represent approximately 27.0 million students. On the basis of self-reported grade level, this included 8,837 middle school questionnaires (approximately 11.9 million students) and 10,097 high school questionnaires (approximately 15.0 million students); 84 questionnaires with missing information on grade level were excluded from school-level analyses. When applicable, estimates were determined overall and by self-reported sex (male or female), race and ethnicity (non-Hispanic white, non-Hispanic black, Hispanic, or non-Hispanic other), and school level (middle school or high school). Results with unweighted denominators $<50$ or a relative standard error $>30 \%$ are not shown.

\section{Measures}

\section{Ever and Current Tobacco Product Use}

Ever and current (past 30-day) use of seven tobacco products was assessed. These products were e-cigarettes, cigarettes, cigars (cigars, little cigars, and cigarillos), smokeless tobacco (chewing tobacco, snuff, dip, snus, and dissolvable tobacco), hookahs, pipe tobacco, and bidis (small brown cigarettes wrapped in a leaf). Ever use was defined as ever trying each respective product, and current use was defined as using each respective product on $\geq 1$ day during the past 30 days. Any tobacco product use was defined as use of one or more of the seven tobacco products. Use of two or more tobacco product types was defined as use of two or more of the seven tobacco products. Any combustible tobacco product use was defined as use of one or more of the following: cigarettes, cigars, hookahs, pipe tobacco, and bidis. Current tobacco product use combinations also were assessed.

\section{Frequency of Tobacco Product Use}

The 2019 NYTS included questions to assess the frequency of tobacco product use among current users of the following tobacco products: e-cigarettes, cigarettes, cigars, smokeless tobacco (chewing tobacco, snuff, or dip), and hookahs. Respondents were asked, "During the past 30 days, on how many days did you (use e-cigarettes; smoke cigarettes; smoke cigars, cigarillos, or little cigars; use chewing tobacco, snuff, or dip; or smoke tobacco in a hookah or water pipe)?" Response options ranged between 0 and 30 days. Consistent with previous 
literature, response options were categorized as 1-5 days, 6-19 days, and 20-30 days for analysis (9). Frequent use was defined as using a product on $\geq 20$ days of the past 30 days.

\section{Flavored Tobacco Product Use}

Flavored tobacco product use was determined by the response to the question, "Which of the following tobacco products that you used in the past 30 days were flavored to taste like menthol (mint), alcohol (wine or cognac), candy, fruit, chocolate, or other sweets?" Participants could select from a list of options to indicate the flavored tobacco product or products they had used. Among students who reported current use of each respective product, those who selected the flavored product were categorized as a flavored product user. Flavored (menthol) cigarette smoking, specifically, was ascertained from responses to two questions: 1) "During the past 30 days, were the cigarettes that you usually smoked menthol?" and 2) "During the past 30 days, what brand of cigarettes did you usually smoke?" Among current cigarette smokers, those reporting "yes" to the menthol question or who reported "Newport" or "Kool" as the usual cigarette brand were categorized as flavored (menthol) cigarette smokers.

\section{Reasons for E-Cigarette Use}

Reasons for e-cigarettes use were assessed by asking ever and current e-cigarette users, "What are the reasons why you have used electronic cigarettes or e-cigarettes?" Respondents could select one or more of 12 specified reasons. Those who indicated "I used them for some other reason" could specify their reason with a write-in response; analysis of these write-in responses ( $n=642$ ) was not included in this report. Reasons for use of other tobacco products were not assessed in the 2019 NYTS.

\section{Exposure to Tobacco Product Marketing}

Exposure to tobacco product marketing (advertisements or promotions) were assessed for four sources: retail stores; Internet; television, streaming sources, or movies; and newspapers or magazines. Exposure was assessed separately for e-cigarettes and cigarettes or other tobacco products. Participants were asked, "When you (are using the Internet; read newspapers or magazines; go to a convenience store, supermarket, or gas station; watch television or streaming services [such as Netflix, Hulu, or Amazon Prime], or go to the movies), how often do you see ads or promotions for (e-cigarettes; cigarettes or other tobacco products)?" Respondents were categorized as exposed if they responded "sometimes," "most of the time," or "always" or unexposed if they responded "never" or "rarely." Persons who reported "I never go to a convenience stores, supermarket, or gas station," "I do not use the Internet," "I do not watch TV or streaming services or go to the movies," or "I do not read newspapers or magazines" were set to missing.

\section{Curiosity and Susceptibility}

The 2019 NYTS included questions to assess curiosity about and susceptibility to the following tobacco products: e-cigarettes, cigarettes, cigars, hookahs, and smokeless tobacco products (chewing tobacco, snuff, or dip). For curiosity, respondents were asked, "Have you ever been curious about (using an e-cigarette; smoking a cigarette; smoking a cigar, cigarillo, or little cigar; using chewing tobacco, snuff, or dip; or smoking tobacco in a hookah or water pipe)?” To capture any level of curiosity, responses were recoded as curious (definitely yes, probably yes, or probably not) and not curious (definitely not). For each of these products, three questions assessed susceptibility: 1) "Do you think that you will try (an e-cigarette; a cigarette; a cigar, cigarillo, or little cigar; chewing tobacco, snuff, or dip; or smoking tobacco in a hookah or water pipe) soon?"; 2) "Do you think you will (use an e-cigarette; smoke a cigarette; smoke a cigar, cigarillo, or little cigar; use chewing tobacco, snuff, or dip; or smoke tobacco in a hookah or water pipe) in the next year?"; and 3) "If one of your best friends were to offer you (an e-cigarette; cigarette; cigar, cigarillo, or little cigar; chewing tobacco, snuff, or dip; or a hookah or water pipe with tobacco), would you (use; smoke; or try) it?" Consistent with previous literature, to differentiate between committed never tobacco product users from susceptible tobacco product users (10), susceptibility for each product was defined as a response other than "definitely not" to any of the three susceptibility questions or the curiosity question. Curiosity and susceptibility were assessed among respective never users of each respective tobacco product.

\section{Harm Perceptions}

The 2019 NYTS included questions to assess harm perceptions of the following tobacco products: e-cigarettes, cigarettes, smokeless tobacco (chewing, snuff, dip, or snus), and hookahs. All respondents were asked, "How much do you think people harm themselves when they (smoke cigarettes; use chewing tobacco, snuff, dip, or snus; use e-cigarettes; or smoke tobacco in a hookah or water pipe) some days but not every day?" Response options included "no harm," "little harm," "some harm," and "a lot of harm."

\section{Urges to Use Tobacco Products}

Current users of any tobacco product were asked two questions: 1) "During the past 30 days, have you had a strong craving or felt like you really needed to use a tobacco product of any kind?" (with response options of yes or no) and 2) "How soon after you wake do you want to use a tobacco product?" (with response options of "I do not want to use tobacco products," within 5 minutes, from 6 to 30 minutes, from $>30$ minutes to 1 hour, after $>1$ hour but $<24$ hours, and "I rarely want to use tobacco products"). 
Consistent with previous literature (11), responses to the second question were dichotomized according to whether the respondent wanted to use a tobacco product within the first 30 minutes of wakening (yes or no).

\section{Quitting Behaviors}

Current users of any tobacco product were asked two questions: 1) "Are you seriously thinking about quitting the use of all tobacco products?" (with response options of "yes, during the next 6 months"; "yes, during the next 12 months"; "yes, but not during the next 12 months"; and "no, I am not thinking about quitting the use of all tobacco products") and 2) "During the past 12 months, how many times have you stopped using all tobacco products for one day or longer, because you were trying to quit tobacco products for good?" (with response options of one time, two times, three to five times, six to nine times, $\geq 10$ times, and "I did not try to quit during the past 12 months"). Responses were dichotomized by whether the respondent was seriously thinking about quitting (yes or no) or made past-year quit attempts (more than one time or did not try quitting).

\section{Results}

\section{Ever Tobacco Product Use}

In 2019, 40.5\% of U.S. middle and high school students (10.9 million) reported having ever tried a tobacco product (Table 1). Among ever tobacco product users, $58.5 \%$ had ever tried a combustible tobacco product and $53.8 \%$ had ever tried two or more tobacco product types. Overall, $53.3 \%$ of high school students ( 8.0 million) and $24.3 \%$ of middle school students (2.9 million) reported ever using any tobacco product. E-cigarettes were the most commonly ever used tobacco product among U.S middle and high school students overall (35.0\%; 9.4 million), among females (35.4\%) and males (35.7\%), and among non-Hispanic whites (38.2\%), Hispanics (35.4\%), non-Hispanic blacks (27.0\%), and non-Hispanics of other races $(24.4 \%)$.

\section{Current Tobacco Product Use}

Overall, $23.0 \%$ of middle and high school students (6.2 million) reported current (past 30-day) use of any tobacco product (Table 2). Among current tobacco product users, $38.3 \%$ currently used any combustible tobacco product and $33.9 \%$ currently used two or more tobacco product types. E-cigarettes were the most commonly used tobacco product overall $(20.0 \% ; 5.4$ million), followed by cigars $(5.3 \%)$, cigarettes $(4.3 \%)$, smokeless tobacco $(3.5 \%)$, hookahs
(2.6\%), and pipe tobacco $(<1.0 \%)$ (Figure 1). Among current tobacco product users, $55.5 \%$ reported use of e-cigarettes only. Moreover, e-cigarettes were the most commonly used product in combination with other tobacco products; among students who reported current use of two or more tobacco products, $17.2 \%$ reported current use of e-cigarettes and cigars, $13.3 \%$ reported current use of e-cigarettes and cigarettes, and $9.8 \%$ reported current use of e-cigarettes and smokeless tobacco (Figure 2).

Among high school students, $31.2 \%$ ( 4.7 million) reported current use of any tobacco product. Among these current tobacco product users, $38.5 \%$ currently used any combustible tobacco product and $34.6 \%$ reported current use of two or more tobacco product types. Among high school students, e-cigarettes were the most commonly used tobacco product $(27.5 \%)$, followed by cigars $(7.6 \%)$, cigarettes $(5.8 \%)$, smokeless tobacco $(4.8 \%)$, hookahs $(3.4 \%)$, and pipe tobacco $(1.1 \%)$.

Among middle school students, $12.5 \%$ (1.5 million) reported current use of any tobacco product. Among these current tobacco product users, $38.4 \%$ used any combustible tobacco product and $32.0 \%$ reported current use of two or more tobacco product types. Among middle school students, e-cigarettes were the most commonly used tobacco product (10.5\%), followed by cigarettes and cigars (both 2.3\%), smokeless tobacco $(1.8 \%)$, and hookahs (1.6\%).

\section{Frequency of Tobacco Product Use}

Among middle and high school students who were current users of each product, the prevalence of frequent tobacco product use ( $\geq 20$ days of the past 30 days) was $34.1 \%$ of smokeless tobacco users $(270,000), 30.4 \%$ of e-cigarette users (1.6 million), $28.9 \%$ of cigarette smokers $(330,000)$, $18.6 \%$ of hookah smokers $(120,000)$, and $16.8 \%$ of cigar smokers $(240,000)$ (Table 3). Most current tobacco product users reported using tobacco products on 1-5 days of the past 30 days, including $69.1 \%$ of hookah smokers, $68.7 \%$ of cigar smokers, $55.9 \%$ of cigarette smokers, $50.8 \%$ of e-cigarette users, and $49.3 \%$ of smokeless tobacco users.

\section{Flavored Tobacco Product Use}

In 2019, 69.6\% (4.3 million) of middle and high school students who currently used tobacco products reported using at least one flavored tobacco product. E-cigarettes were the most commonly used flavored tobacco product $(68.8 \%$ of current e-cigarette users; 3.7 million). The proportion of other current tobacco product users who reported flavored product use was $48.0 \%$ for smokeless tobacco, $46.7 \%$ for cigarettes (menthol only), $41.9 \%$ for cigars, $31.4 \%$ for pipe tobacco, and $31.2 \%$ 
FIGURE 1. Percentage of middle and high school students who currently use any tobacco product, ${ }^{*}$ any combustible tobacco product, ${ }^{\dagger}$ two or more tobacco product types, ${ }^{\S}$ and selected tobacco products, by school level ${ }^{\mathbb{9}}$ and overall — National Youth Tobacco Survey, United States, 2019

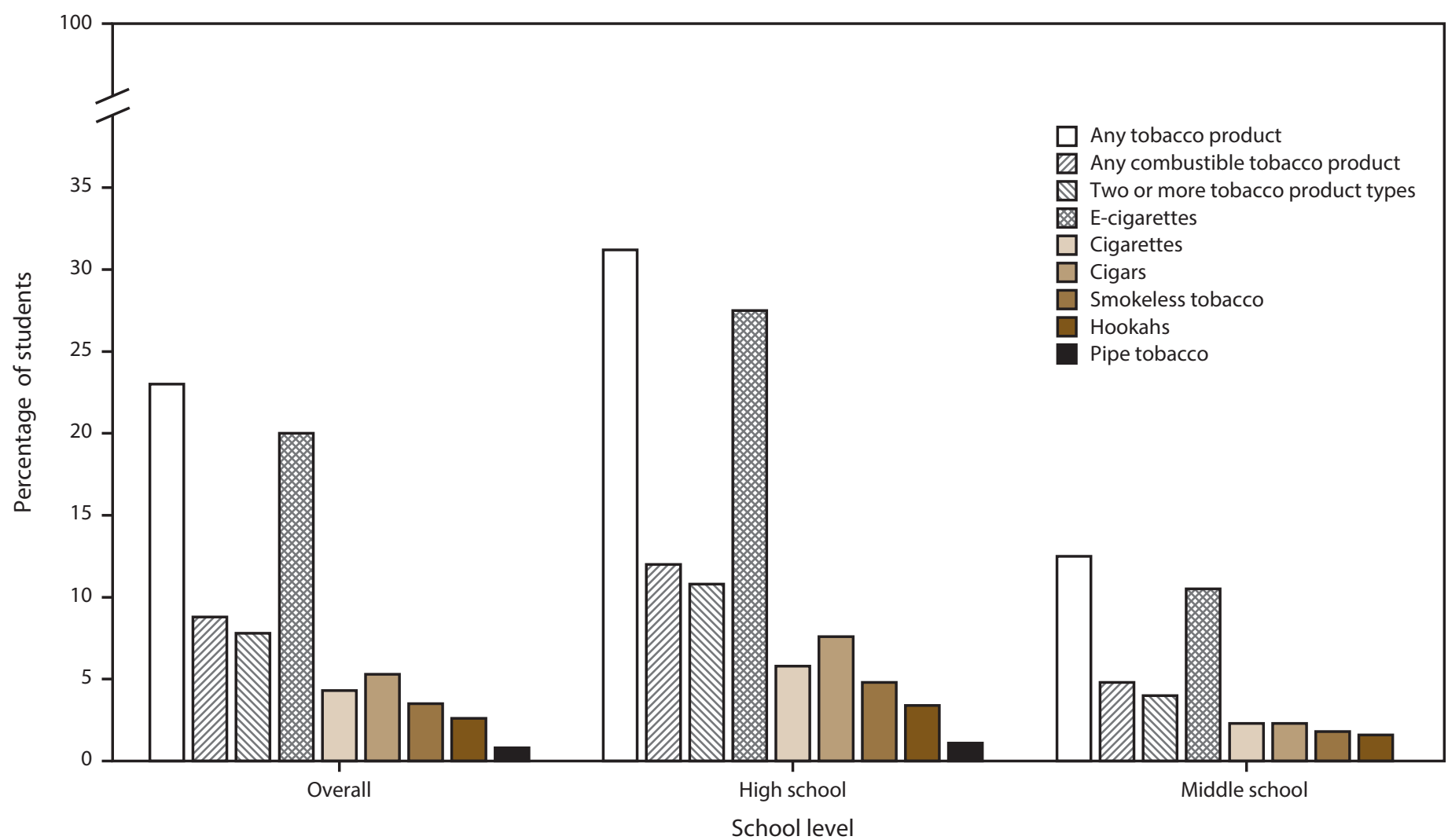

Abbreviation: E-cigarettes = electronic cigarettes.

* Any tobacco product use was defined as use of e-cigarettes, cigarettes, cigars, hookahs, smokeless tobacco (chewing tobacco, snuff, dip, snus, or dissolvable tobacco products), pipe tobacco, or bidis (small brown cigarettes wrapped in a leaf) on $\geq 1$ day during the past 30 days.

+ Any combustible tobacco product use was defined as use of cigarettes, cigars, hookahs, pipe tobacco, or bidis on $\geq 1$ day during the past 30 days.

$\S$ Defined as use of two or more tobacco products (e-cigarettes, cigarettes, cigars, hookahs, smokeless tobacco, pipe tobacco, or bidis) on $\geq 1$ day during the past 30 days.

I On the basis of self-reported grade level among high school students (grades 9-12) and middle school students (grades 6-8), respectively. Current use of pipe tobacco among middle school students is not shown because of unweighted denominator $<50$ or a relative standard error $>30 \%$.

for hookahs (Table 4). Among current tobacco product users, flavored tobacco product use was $72.8 \%$ among high school students and 59.6\% among middle school students. Flavored tobacco product use was highest among non-Hispanic whites $(76.8 \%)$ compared with students of other non-Hispanic races (68.1\%), Hispanics (63.1\%), and non-Hispanic blacks (48.0\%). The proportion of current tobacco users who used flavored products was $68.6 \%$ among females and $70.7 \%$ among males.

\section{Reasons for E-Cigarette Use}

Among middle and high school students who ever tried using e-cigarettes, the most common reasons for e-cigarette use were "I was curious about them" (55.3\%), "friend or family member used them" (30.8\%), "they are available in flavors, such as mint, candy, fruit or chocolate" (22.4\%), and "I can use them to do tricks" (21.2\%) (Table 5). "I was curious about them" was the most commonly reported reason among current exclusive e-cigarette users (56.1\%) and students who currently used both e-cigarettes and at least one other tobacco product (38.4\%) (Table 6).

\section{Exposure to Tobacco Product Marketing}

In 2019, NYTS data indicated that $86.3 \%$ of middle and high school students who reported contact with a potential source of tobacco product advertisements or promotions (going to a convenience store, supermarket, or gas station; using the Internet; watching television or streaming services or going to the movies; reading newspapers or magazines) reported exposure to any tobacco product marketing (Table 7). The prevalence of exposure was $79.4 \%$ among students who reported going to retail stores, $59.6 \%$ among those who reported using the Internet, $53.5 \%$ among those who reported reading newspapers or magazines, and $36.9 \%$ among those who reported watching television or streaming services or 
FIGURE 2. Percentage of middle and high school students who reported current use of two or more tobacco product types, ${ }^{*}$ by product combination $^{\dagger, \S}$ - National Youth Tobacco Survey, United States, 2019

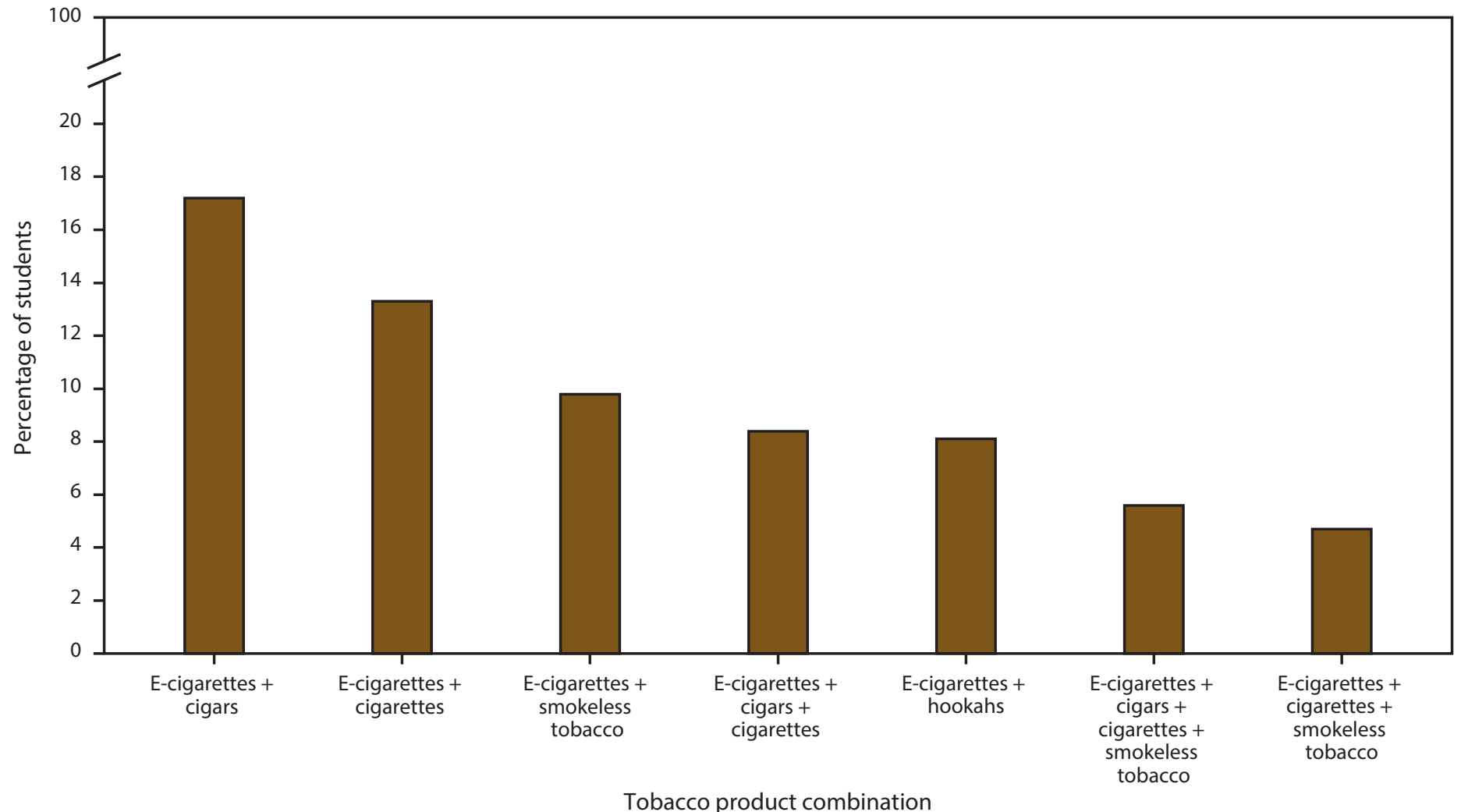

Abbreviation: E-cigarettes = electronic cigarettes.

* Percentages were calculated among youths who used two or more of the following seven tobacco product types on $\geq 1$ day during the past 30 days: e-cigarettes, cigarettes, cigars, smokeless tobacco (chewing tobacco, snuff, dip, snus, or dissolvable tobacco products), hookahs, pipe tobacco, or bidis (small brown cigarettes wrapped in a leaf).

${ }^{\dagger}$ A total of 120 distinct combinations was assessed (21 two-product type combinations, 35 three-product type combinations, 35 four-product type combinations, 21 five-product type combinations, seven six-product type combinations, and one seven-product type combination).

$\S$ All other 113 tobacco product combinations not shown were statistically unreliable because of unweighted denominator $<50$ or a relative standard error $>30 \%$.

going to the movies. Overall, $69.3 \%$ of middle and high school students reported exposure to e-cigarette marketing specifically, whereas $81.7 \%$ reported exposure to cigarette or other tobacco product marketing.

\section{Curiosity About and Susceptibility to Tobacco Product Use}

Among middle and high school students who were never users of the specific tobacco product, $39.1 \%$ were curious about using e-cigarettes, $37.0 \%$ were curious about smoking cigarettes, $28.0 \%$ were curious about smoking cigars, $23.2 \%$ were curious about smoking hookahs, and $15.9 \%$ were curious about using smokeless tobacco products (Table 8). Among never users of the specific tobacco product, $45.9 \%$ reported susceptibility to cigarettes, followed by e-cigarettes $(45.0 \%)$, cigars $(35.9 \%)$, hookahs $(29.9 \%)$, and smokeless tobacco products $(21.2 \%)$. Susceptibility to using e-cigarettes was $46.9 \%$ among females and $43.4 \%$ among males. Susceptibility to using e-cigarettes and smoking cigarettes was higher among middle school students ( $47.0 \%$ and $49.5 \%$, respectively) than among high school students ( $42.8 \%$ and $42.7 \%$, respectively).

\section{Harm Perceptions}

The percentage of middle school and high school students who reported that intermittent use of tobacco products causes a lot of harm was highest for cigarettes (54.9\%), followed by smokeless tobacco products $(52.5 \%)$, hookahs $(44.9 \%)$, and e-cigarettes (32.3\%) (Figure 3). The percentage of students who reported that intermittent use causes no or little harm was highest for e-cigarettes (28.2\%), followed by hookahs (16.4\%), smokeless tobacco products (11.5\%), and cigarettes $(9.5 \%)$.

\section{Urges to Use Tobacco Products}

Among current users of any tobacco product, $24.7 \%$ reported experiencing cravings to use tobacco products during the past 30 days, including $25.8 \%$ of high school students and 
FIGURE 3. Harm perceptions of intermittent use of e-cigarettes, cigarettes, smokeless tobacco, and hookahs* reported by middle and high school students - National Youth Tobacco Survey, United States, 2019

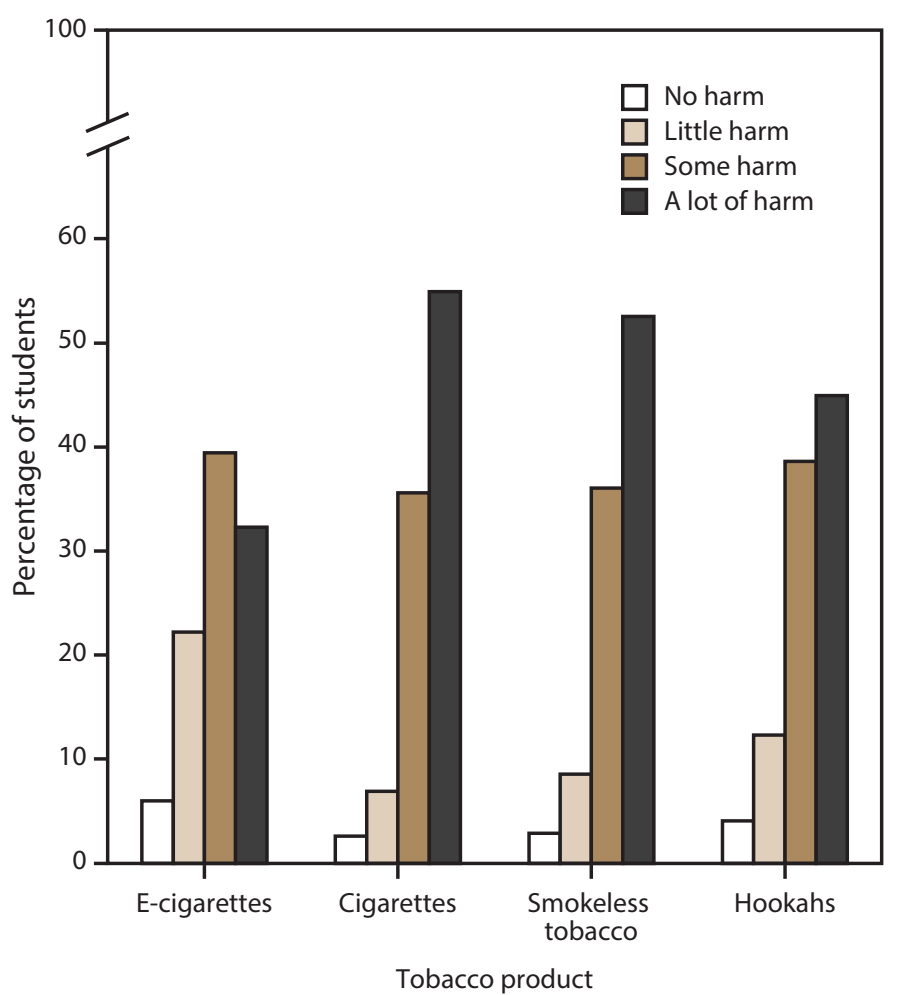

Abbreviation: E-cigarettes = electronic cigarettes.

* Assessed by the questions, "How much do you think people harm themselves when they (smoke cigarettes; use chewing tobacco, snuff, dip, snus, or dissolvable tobacco products; use e-cigarettes; or smoke tobacco in a hookah or water pipe) some days but not every day?" Response options included "no harm,"'little harm," "some harm," and "a lot of harm" for each of the four tobacco products assessed. Harm perceptions of intermittent use of other tobacco products were not assessed in the 2019 National Youth Tobacco Survey.

$21.4 \%$ of middle school students (Table 9). The prevalence of experiencing cravings was reported by $28.7 \%$ of non-Hispanic whites, $18.3 \%$ of Hispanics, and $15.8 \%$ of non-Hispanic blacks. Overall, $13.7 \%$ of current tobacco product users reported wanting to use a tobacco product within 30 minutes of waking, including $15.6 \%$ of high school students and $7.3 \%$ of middle school students. The prevalence of wanting to use a tobacco product within 30 minutes of waking was reported by $16.5 \%$ of non-Hispanic white and $9.2 \%$ of Hispanic students.

\section{Quitting Behaviors}

Among current users of any tobacco product, 57.8\% reported they were seriously thinking about quitting the use of all tobacco products (Table 9). By school level, $57.7 \%$ of high school student current users and $57.9 \%$ of middle school student current users reported they were seriously thinking about quitting. Furthermore, $57.5 \%$ of current tobacco product users reported they stopped using all tobacco products for $\geq 1$ day because they were trying to quit, including $55.7 \%$ of high school students and $63.3 \%$ of middle school students.

\section{Discussion}

\section{Public Health Implications}

Findings from the 2019 NYTS indicate that approximately two in five students (40.5\%), including approximately half of high school students $(53.3 \%)$ and one in four middle school students $(24.3 \%)$, had ever tried a tobacco product. Furthermore, approximately one in four students (23.0\%), including approximately three in 10 high school students $(31.2 \%)$ and one in eight middle school students (12.5\%), had used a tobacco product during the past 30 days. Approximately one in three current tobacco product users $(33.9 \%)$ reported using multiple tobacco products; youths who use multiple tobacco products are at higher risk for developing nicotine dependence and might be more likely to continue using tobacco into adulthood $(1,2)$. Although most current youth tobacco product users are not daily users $(9,12,13)$, estimates of frequent e-cigarette use among high school students were comparable to those observed for cigarette and smokeless tobacco product users in 2019. However, even infrequent tobacco product use ( $1-5$ days during the past 30 days) can lead to symptoms of nicotine dependence (11); in 2019, among current tobacco product users, approximately one in four high school students and one in five middle school students reported having cravings for tobacco products. Youth use of tobacco products in any form is unsafe, regardless of whether the products are smoked, smokeless, or electronic $(2,3)$. Continued efforts are warranted to prevent and reduce all forms of tobacco product use among U.S. youths.

In 2019, the prevalence of cigarette smoking among youths was the lowest ever captured by the NYTS since 1999. An estimated $5.8 \%$ of high school students and $2.3 \%$ of middle school students reported current cigarette smoking in 2019, compared with $28.5 \%$ of high school students and $9.2 \%$ of middle school students in 1999 (14). However, youths are using various other tobacco products, most notably e-cigarettes.

Since 2014, e-cigarettes have remained the most commonly used tobacco product among U.S. youths $(15,16)$. During 2017-2018, current e-cigarette use increased by $77.8 \%$ among high school students and $48.5 \%$ among middle school students $(16,17)$. The 2017-2018 surge in e-cigarette use prompted the U.S. Surgeon General to issue an advisory declaring e-cigarette use among youths an epidemic in December 2018. This advisory underscored the importance of protecting youths from a lifetime of nicotine dependency and associated health risks 
(18). In 2019, approximately three in 11 high school students $(27.5 \%)$ and one in 10 middle school students (10.5\%) used e-cigarettes during the past 30 days, which is higher than estimates observed in the 2018 NYTS $(16,17)$. However, direct attribution of this change to actual increases in product use is not possible because changes made to the 2019 survey could also lead to higher estimates of use. Changes included the electronic mode of survey administration, preamble descriptions (e.g., specific brand examples), and tobacco product images.*

The 2019 NYTS offers insights into factors known to promote tobacco product use among youths. For example, tobacco marketing can prompt tobacco product initiation and use among youths $(2,3,19)$. Flavors in tobacco products can increase the appeal of tobacco products to youths $(2,3)$. Measuring curiosity and susceptibility can help identify youths who might progress from nonuse to experimentation and further progression to established tobacco product use (20-23). Although the 2009 Family Smoking Prevention and Tobacco Control Act ${ }^{\dagger}$ prohibits characterizing flavors other than tobacco and menthol in cigarettes, characterizing flavors in other tobacco products, such as e-cigarettes, are widely available $(24,25)$. Efforts to address these factors, including strategies to curb e-cigarette marketing that is appealing to young persons and strategies to reduce access to flavored tobacco products by young persons, could help prevent and reduce tobacco product use by youths (18). In March 2019, FDA published a draft guidance proposing to end the previous compliance policy as it applied to flavored e-cigarettes and other electronic nicotine delivery systems (ENDS) and prioritizing enforcement of flavored ENDS products, including warning letters and civil money penalties for ENDS that do not have a marketing authorization from FDA (26).

Because of the especially high prevalence of e-cigarette use among U.S. youths, increasing successful quit attempts could complement prevention efforts to reduce tobacco product use among youths. In 2019, approximately half of middle and

\footnotetext{
${ }^{*}$ The 2018 NYTS questionnaire provided the following descriptive preamble for e-cigarettes: "The next 11 questions are about electronic cigarettes or e-cigarettes. E-cigarettes are battery powered devices that usually contain a nicotine-based liquid that is vaporized and inhaled. You may also know them as e-cigs, vape-pens, hookah-pens, e-hookahs, e-cigars, e-pipes, personal vaporizers, or mods. Some brand examples include NJOY, Blu, Vuse, MarkTen, Logic, Vapin Plus, eGo, and Halo." The 2019 NYTS questionnaire provided the following descriptive preamble for e-cigarettes: "The next several questions are about electronic cigarettes or e-cigarettes. Some brand examples include JUUL, Vuse, MarkTen, and blu. E-cigarettes are battery powered devices that usually contain a nicotine-based liquid that is vaporized and inhaled. You may also know them as e-cigs, vape-pens, e-hookahs, vapes, or mods." In the 2019 questionnaire, preambles for each tobacco product section, including e-cigarettes, contained images showing examples of each respective product.

${ }^{\dagger}$ Family Smoking Prevention and Tobacco Control Act, Pub. L. No. 111-31, H.R. 1256 (June 22, 2009).
}

high school current tobacco product users reported seriously thinking about quitting all tobacco products or making a pastyear quit attempt. The U.S. Preventive Services Task Force recommends that primary care clinicians provide interventions, including education or brief counseling, to prevent initiation of tobacco use among school-aged children and adolescents (27). Additional tailored interventions and services could further support cessation of all tobacco product use among youths.

\section{Public Health Action}

The sustained implementation of population-based strategies, along with regulation of tobacco products by FDA, is critical to preventing and reducing all forms of tobacco product use among youths $(1-3,18)$. Strategies to reduce tobacco product use and initiation among youths include increasing prices of tobacco products; protecting persons from exposure to secondhand smoke and e-cigarette aerosol; sustaining hard-hitting media campaigns that warn about the dangers of tobacco product use; restricting youth access to tobacco products, including increasing the minimum age for purchase of tobacco products to 21 years; and prohibiting the sale of flavored tobacco products $(1,16,18,28)$.

Everyone can help protect youths from the harms of tobacco products, including e-cigarettes $(3,18)$. Parents and educators can learn about the different types of e-cigarettes available, including discreet devices shaped like USB flash drives (e.g., JUUL). They and others who influence youths can set a positive example by being tobacco free and communicating that nicotine use can lead to addiction and can harm the developing brain and affect learning, memory, and attention (3). Schools can adopt and enforce tobacco-free campus policies that include e-cigarettes and reject tobacco industry-sponsored prevention programs. Of the tobacco industry-sponsored prevention programs that have been studied, none have been shown to be effective (2). Furthermore, health care providers can ask about the use of all tobacco products, including e-cigarettes, when screening patients for tobacco product use and assisting those who want to quit using tobacco products.

\section{Limitations}

The findings in this report are subject to at least three limitations. First, because NYTS transitioned survey administration modes from a paper and pencil survey to an electronic survey in 2019, statistical tests comparing measures with previous years were not done. Second, data were selfreported and might be subject to recall and response bias. However, the validity of self-reported tobacco product use is consistently high in population-based studies $(29,30)$. Finally, 
data were collected only from middle and high school students who attended public or private schools; findings might not be generalizable to youths who are home schooled, have dropped out of school, are in detention centers, or are enrolled in alternative schools. However, data from the Current Population Survey indicate that approximately $97 \%$ of U.S. youths aged 10-17 years were enrolled in a traditional school in 2017 (31).

\section{Conclusion}

NYTS is the only comprehensive, nationally representative survey of U.S. middle and high school students focused on tobacco product use behaviors and associated factors. Findings from NYTS indicate that in 2019, approximately half of high school students (53.3\%) and one in four middle school students $(24.3 \%)$ had ever used a tobacco product. Furthermore, approximately three in 10 high school students (31.2\%) and approximately one in eight middle school students (12.5\%) had used a tobacco product during the past 30 days. Multiple factors known to promote tobacco product use and initiation among youths $(2,3)$, including flavored tobacco products, marketing, curiosity and susceptibility, and misperceptions of harm, remained prevalent. The comprehensive and sustained implementation of evidence-based tobacco control strategies, combined with FDA's regulation of tobacco products, is important for preventing and reducing all forms of tobacco product use among U.S. youths. In addition, because tobacco products might continue to diversify, surveillance among youths for all forms of tobacco product use and associated factors is important to the development of public health policy and action at the national, state, and community levels.

\section{Conflict of Interest}

All authors have completed and submitted the International Committee of Medical Journal Editors form for disclosure of potential conflicts of interest. No potential conflicts of interest were disclosed.

\section{References}

1. US Department of Health and Human Services. The health consequences of smoking - 50 years of progress. Atlanta, GA: US Department of Health and Human Services, CDC; 2014. https://www.ncbi.nlm.nih. gov/books/NBK179276/pdf/Bookshelf_NBK179276.pdf

2. US Department of Health and Human Services. Preventing tobacco use among youth and young adults. Atlanta, GA: US Department of Health and Human Services, CDC; 2012. https://www.cdc.gov/tobacco/ data_statistics/sgr/2012/index.htm

3. US Department of Health and Human Services. E-cigarette use among youth and young adults. Atlanta, GA: US Department of Health and Human Services, CDC; 2016. https://www.cdc.gov/tobacco/ data_statistics/sgr/e-cigarettes/pdfs/2016_sgr_entire_report_508.pdf
4. CDC. National Youth Tobacco Survey. https://www.cdc.gov/tobacco/ data_statistics/surveys/nyts/index.htm

5. Market Data Retrieval. National education database master extract. Shelton, CT: Market Data Retrieval; 2019.

6. US Department of Education, National Center for Education Statistics. Common core of data: America's public schools. Washington, DC: US Department of Education, National Center for Education Statistics. https://nces.ed.gov/ccd/

7. US Department of Education, National Center for Education Statistics. Private School Universe Survey (PSS). Washington, DC: US Department of Education, National Center for Education Statistics. https://nces. ed.gov/surveys/pss/

8. Research Triangle Institute. SUDAAN, version 11.0.1 [software and documentation]. Research Triangle Park, NC: Research Triangle Institute; 2013. https://www.rti.org/impact/sudaan-statistical-softwareanalyzing-correlated-data

9. Anic GM, Sawdey MD, Jamal A, Trivers KF. Frequency of use among middle and high school student tobacco product users-United States, 2015-2017. MMWR Morb Mortal Wkly Rep 2018;67:1353-7. https:// doi.org/10.15585/mmwr.mm6749a1

10. Nodora J, Hartman SJ, Strong DR, et al. Curiosity predicts smoking experimentation independent of susceptibility in a US national sample. Addict Behav 2014;39:1695-700. https://doi.org/10.1016/j. addbeh.2014.06.002

11. Apelberg BJ, Corey CG, Hoffman AC, et al. Symptoms of tobacco dependence among middle and high school tobacco users: results from the 2012 National Youth Tobacco Survey. Am J Prev Med 2014;47(Suppl 1):S4-14. https://doi.org/10.1016/j.amepre.2014.04.013

12. Substance Abuse and Mental Health Services Administration. Results from the 2017 National Survey on Drug Use and Health: detailed tables. Rockville, MD: Substance Abuse and Mental Health Services Administration. https://www.samhsa.gov/data/sites/default/files/ cbhsq-reports/NSDUHDetailedTabs2017/NSDUHDetailedTabs2017. htm\#lotsect2pe

13. Kann L, McManus T, Harris WA, et al. Youth risk behavior surveillanceUnited States, 2017. MMWR Surveill Summ 2018;67(No. SS-8). https://doi.org/10.15585/mmwr.ss6708a1

14. Ahern $\mathrm{CH}$, Batchelor SM, Blanton CJ, et al. Youth tobacco surveillance-United States, 1998-1999. MMWR Surveill Summ 2000;49(No. SS-10).

15. Arrazola RA, Dube SR, King BA. Tobacco product use among middle and high school students-United States, 2011 and 2012. MMWR Morb Mortal Wkly Rep 2013;62:893-7.

16. Gentzke AS, Creamer M, Cullen KA, et al. Vital signs: tobacco product use among middle and high school students_-United States, 2011-2018. MMWR Morb Mortal Wkly Rep 2019;68:157-64. https://doi. org/10.15585/mmwr.mm6806e1

17. Cullen KA, Ambrose BK, Gentzke AS, Apelberg BJ, Jamal A, King BA. Notes from the field: use of electronic cigarettes and any tobacco product among middle and high school students—United States, 2011-2018. MMWR Morb Mortal Wkly Rep 2018;67:1276-7. https://doi. org/10.15585/mmwr.mm6745a5

18. US Department of Health and Human Services. Surgeon General's advisory on e-cigarette use among youth. Washington, DC: US Department of Health and Human Services, Office of the Surgeon General; 2018. https://e-cigarettes.surgeongeneral.gov/documents/ surgeon-generals-advisory-on-e-cigarette-use-among-youth-2018.pdf

19. Singh T, Agaku IT, Arrazola RA, et al. Exposure to advertisements and electronic cigarette use among US middle and high school students. Pediatrics 2016;137:e20154155. https://doi.org/10.1542/ peds.2015-4155 
20. Pierce JP, Choi WS, Gilpin EA, Farkas AJ, Merritt RK. Validation of susceptibility as a predictor of which adolescents take up smoking in the United States. Health Psychol 1996;15:355-61. https://doi. org/10.1037/0278-6133.15.5.355

21. Pierce JP, Distefan JM, Kaplan RM, Gilpin EA. The role of curiosity in smoking initiation. Addict Behav 2005;30:685-96. https://doi. org/10.1016/j.addbeh.2004.08.014

22. Portnoy DB, Wu CC, Tworek C, Chen J, Borek N. Youth curiosity about cigarettes, smokeless tobacco, and cigars: prevalence and associations with advertising. Am J Prev Med 2014;47(Suppl 1):S76-86. https:// doi.org/10.1016/j.amepre.2014.04.012

23. Gentzke AS, Wang B, Robinson JN, Phillips E, King BA. Curiosity about and susceptibility toward hookah smoking among middle and high school students. Prev Chronic Dis 2019;16:E04. https://doi. org/10.5888/pcd16.180288

24. US Food and Drug Administration. Deeming tobacco products to be subject to the federal Food, Drug, and Cosmetic Act, as amended by the Family Smoking Prevention and Tobacco Control Act; restrictions on the sale and distribution of tobacco products and required warning statements for tobacco products. Final rule. Fed Regist 2016;81:28973-9106.

25. Zhu SH, Sun JY, Bonnevie E, et al. Four hundred and sixty brands of e-cigarettes and counting: implications for product regulation. Tob Control 2014;23(Suppl 3):iii3-9. https://doi.org/10.1136/ tobaccocontrol-2014-051670
26. Food and Drug Administration, Center for Tobacco Products. Modifications to compliance policy for certain deemed tobacco products: guidance for industry. Silver Spring, MD: US Department of Health and Human Services, Food and Drug Administration, Center for Tobacco Products; 2019. https:// www.fda.gov/regulatory-information/search-fda-guidance-documents/ modifications-compliance-policy-certain-deemed-tobacco-products

27. US Preventive Services Task Force. Primary care interventions to prevent tobacco use in children and adolescents. Rockville, MD: US Preventive Services Task Force; 2013. https://www.uspreventiveservicestaskforce.org/

28. CDC. Best practices for comprehensive tobacco control programs - 2014. Atlanta, GA: US Department of Health and Human Services, CDC; 2014. https://www.cdc.gov/tobacco/stateandcommunity/best_practices/ index.htm

29. Binnie V, McHugh S, Macpherson L, Borland B, Moir K, Malik K. The validation of self-reported smoking status by analysing cotinine levels in stimulated and unstimulated saliva, serum and urine. Oral Dis 2004;10:287-93. https://doi.org/10.1111/j.1601-0825.2004.01018.x

30. Boykan R, Messina CR, Chateau G, Eliscu A, Tolentino J, Goniewicz ML. Self-reported use of tobacco, e-cigarettes, and marijuana versus urinary biomarkers. Pediatrics 2019;143:e20183531. https://doi.org/10.1542/ peds.2018-3531

31. US Census Bureau. School enrollment in the United States: October 2017_detailed tables. https://www.census.gov/data/tables/2017/demo/ school-enrollment/2017-cps.html 
TABLE 1. Percentage of middle and high school students who reported ever using tobacco products, by product, ${ }^{*}$ school level, sex, and race/ethnicity - National Youth Tobacco Survey, United States, 2019

\begin{tabular}{|c|c|c|c|c|c|c|c|c|}
\hline \multirow[b]{3}{*}{ Tobacco product } & \multicolumn{2}{|c|}{ Sex } & \multicolumn{4}{|c|}{ Race/Ethnicity } & & \\
\hline & \multirow{2}{*}{$\begin{array}{c}\text { Female } \\
\%(95 \% \mathrm{Cl})\end{array}$} & \multirow{2}{*}{$\begin{array}{c}\text { Male } \\
\%(95 \% \mathrm{Cl})\end{array}$} & \multirow{2}{*}{$\begin{array}{c}\text { White, } \\
\text { non-Hispanic } \\
\%(95 \% \mathrm{Cl})\end{array}$} & \multirow{2}{*}{$\begin{array}{c}\begin{array}{c}\text { Black, } \\
\text { non-Hispanic }\end{array} \\
\%(95 \% \mathrm{Cl})\end{array}$} & \multirow{2}{*}{$\begin{array}{l}\text { Hispanic }^{\dagger} \\
\%(95 \% \mathrm{Cl})\end{array}$} & \multirow{2}{*}{$\begin{array}{c}\begin{array}{c}\text { Other, } \\
\text { non-Hispanic }\end{array} \\
\%(95 \% \mathrm{Cl})\end{array}$} & \multicolumn{2}{|c|}{ Total } \\
\hline & & & & & & & $\%(95 \% \mathrm{Cl})$ & $\begin{array}{c}\text { Estimated } \\
\text { weighted no. }\end{array}$ \\
\hline \multicolumn{9}{|l|}{$\overline{\text { Overall }}$} \\
\hline E-cigarettes & $34.5(32.1-36.9)$ & 35.7 (32.9-38.5) & $38.2(35.7-40.8)$ & $27.0(24.1-30.1)$ & $35.4(32.6-38.3)$ & $24.4(20.2-29.1)$ & $35.0(32.9-37.2)$ & $9,430,000$ \\
\hline Cigarettes & $14.2(12.6-15.9)$ & $18.3(15.2-22.0)$ & $18.4(15.8-21.3)$ & $11.8(9.5-14.4)$ & $15.8(13.2-18.8)$ & $9.6(7.1-12.9)$ & $16.4(14.2-18.7)$ & $4,410,000$ \\
\hline Cigars & $11.8(10.4-13.3)$ & $16.9(14.0-20.2)$ & $14.9(12.8-17.2)$ & $17.9(15.2-21.1)$ & $13.3(11.0-16.1)$ & $7.2(5.2-9.9)$ & $14.4(12.6-16.4)$ & $3,880,000$ \\
\hline Smokeless tobacco & $5.1(4.1-6.4)$ & $13.1(10.5-16.2)$ & $11.8(9.5-14.6)$ & $4.6(3.4-6.3)$ & $6.8(5.3-8.5)$ & $5.7(4.1-8.0)$ & $9.2(7.5-11.3)$ & $2,480,000$ \\
\hline Hookahs & $6.9(5.8-8.2)$ & $7.3(5.4-9.9)$ & $5.8(4.5-7.3)$ & $10.1(7.5-13.4)$ & $8.7(6.8-10.9)$ & $6.2(4.6-8.4)$ & $7.1(5.8-8.6)$ & $1,910,000$ \\
\hline Pipe tobacco & $1.8(1.4-2.1)$ & $3.8(2.5-5.8)$ & $3.2(2.2-4.6)$ & -q & $2.5(1.8-3.4)$ & - & $2.8(2.1-3.8)$ & 750,000 \\
\hline $\begin{array}{l}\text { Any tobacco } \\
\text { product }^{* *}\end{array}$ & $39.6(37.1-42.3)$ & $41.5(38.4-44.6)$ & $42.4(39.5-45.4)$ & $38.4(34.3-42.7)$ & $40.8(37.8-43.9)$ & $29.3(25.0-33.9)$ & $40.5(38.2-43.0)$ & $10,930,000$ \\
\hline $\begin{array}{l}\text { Any combustible } \\
\text { tobacco product }^{\dagger \dagger}\end{array}$ & $21.7(19.8-23.8)$ & $25.6(22.3-29.1)$ & $23.7(21.1-26.6)$ & $27.1(23.2-31.4)$ & $24.0(21.3-27.0)$ & $15.7(12.5-19.7)$ & $23.7(21.5-26.1)$ & $6,390,000$ \\
\hline $\begin{array}{l}\text { Two or more tobacco } \\
\text { products } \S \S\end{array}$ & $19.2(17.4-21.1)$ & $24.2(21.0-27.9)$ & $23.1(20.4-26.0)$ & $20.7(17.8-24.0)$ & $21.7(19.1-24.6)$ & $13.0(10.3-16.2)$ & $21.8(19.6-24.1)$ & $5,870,000$ \\
\hline \multicolumn{9}{|l|}{ High school } \\
\hline E-cigarettes & $46.2(43.4-49.1)$ & $47.7(43.8-51.7)$ & $52.2(49.4-54.9)$ & $33.8(29.8-38.0)$ & $44.9(41.1-48.8)$ & $33.4(27.5-39.9)$ & $46.9(44.2-49.7)$ & $7,040,000$ \\
\hline Cigarettes & $19.2(16.7-21.9)$ & $25.7(20.7-31.3)$ & $25.9(22.2-30.0)$ & $14.5(11.2-18.6)$ & $21.1(17.0-25.8)$ & $12.8(8.6-18.6)$ & $22.6(19.3-26.2)$ & $3,390,000$ \\
\hline Cigars & $16.8(14.9-18.8)$ & $24.5(20.1-29.4)$ & $22.0(18.9-25.5)$ & $24.6(21.5-27.8)$ & $17.9(14.4-22.0)$ & $10.0(6.9-14.2)$ & $20.8(18.1-23.7)$ & $3,110,000$ \\
\hline Smokeless tobacco & $6.6(4.9-8.8)$ & $17.8(14.0-22.2)$ & $16.2(12.9-20.1)$ & $5.7(3.8-8.5)$ & $8.1(6.1-10.7)$ & $7.9(5.5-11.1)$ & $12.5(9.9-15.6)$ & $1,870,000$ \\
\hline Hookahs & $9.4(7.7-11.4)$ & $10.4(7.7-14.8)$ & $8.1(6.0-10.8)$ & $14.8(11.3-19.2)$ & $11.8(9.0-15.3)$ & $8.5(6.1-11.8)$ & $9.9(7.9-12.4)$ & $1,480,000$ \\
\hline Pipe tobacco & $2.0(1.6-2.6)$ & $5.5(3.4-8.8)$ & $4.5(3.0-6.8)$ & - & $2.9(1.9-4.6)$ & - & $3.8(2.6-5.6)$ & 570,000 \\
\hline Any tobacco product & $52.4(49.5-55.2)$ & $54.2(50.1-58.2)$ & $56.9(53.7-60.1)$ & $47.6(43.1-52.1)$ & $51.0(47.2-54.8)$ & $38.9(32.9-45.2)$ & $53.3(50.5-56.1)$ & $8,010,000$ \\
\hline $\begin{array}{l}\text { Any combustible } \\
\text { tobacco product }\end{array}$ & $28.9(26.2-31.7)$ & $35.0(30.2-40.1)$ & $32.9(29.2-36.8)$ & $35.3(31.1-39.7)$ & $30.9(27.0-35.2)$ & $20.5(15.3-26.8)$ & $32.1(29.0-35.4)$ & $4,820,000$ \\
\hline $\begin{array}{l}\text { Two or more tobacco } \\
\text { products }\end{array}$ & $25.9(23.5-28.5)$ & $33.6(28.7-38.8)$ & $32.2(28.6-36.1)$ & $27.5(24.0-31.3)$ & $28.3(24.4-32.5)$ & $17.3(13.0-22.7)$ & $29.9(26.8-33.2)$ & $4,490,000$ \\
\hline \multicolumn{9}{|l|}{ Middle school } \\
\hline E-cigarettes & $19.9(18.1-21.8)$ & $19.9(17.9-22.1)$ & $19.3(17.3-21.4)$ & $18.4(15.5-21.8)$ & $23.9(21.6-26.4)$ & $12.6(9.4-16.8)$ & $19.9(18.3-21.6)$ & $2,350,000$ \\
\hline Cigarettes & $8.0(6.6-9.7)$ & $8.7(7.5-10.0)$ & $8.2(6.7-9.9)$ & $8.4(6.3-11.0)$ & $9.2(7.6-11.1)$ & - & $8.4(7.2-9.7)$ & 990,000 \\
\hline Cigars & $5.5(4.3-7.2)$ & $7.0(5.9-8.3)$ & $5.1(4.2-6.3)$ & $9.6(6.8-13.7)$ & $7.7(6.3-9.3)$ & - & $6.3(5.2-7.6)$ & 740,000 \\
\hline Smokeless tobacco & $3.1(2.3-4.3)$ & $6.9(5.6-8.4)$ & $5.9(4.5-7.7)$ & - & $5.0(3.9-6.5)$ & - & $5.0(4.1-6.2)$ & 590,000 \\
\hline Hookahs & $3.8(3.0-4.8)$ & $3.3(2.6-4.2)$ & $2.7(2.0-3.6)$ & $4.2(2.9-5.9)$ & $4.9(3.7-6.5)$ & - & $3.5(2.9-4.4)$ & 410,000 \\
\hline Pipe tobacco & $1.4(1.1-1.8)$ & $1.7(1.3-2.2)$ & $1.4(1.0-2.0)$ & - & - & - & $1.6(1.3-1.9)$ & 180,000 \\
\hline Any tobacco product & $23.8(21.5-26.2)$ & $24.8(22.5-27.2)$ & $22.7(20.4-25.3)$ & $26.9(22.8-31.5)$ & $28.3(25.7-31.0)$ & $16.3(12.4-21.2)$ & $24.3(22.4-26.3)$ & $2,880,000$ \\
\hline $\begin{array}{l}\text { Any combustible } \\
\text { tobacco product }\end{array}$ & $12.8(11.1-14.8)$ & $13.2(11.5-15.0)$ & $11.2(9.7-13.0)$ & $16.8(12.9-21.6)$ & $15.5(13.4-17.8)$ & $9.3(6.2-13.8)$ & $13.0(11.5-14.7)$ & $1,540,000$ \\
\hline $\begin{array}{l}\text { Two or more tobacco } \\
\text { products }\end{array}$ & $10.9(9.3-12.7)$ & $12.0(10.5-13.7)$ & $10.6(8.9-12.6)$ & $12.2(9.6-15.2)$ & $13.8(11.9-15.9)$ & - & $11.5(10.1-13.0)$ & $1,360,000$ \\
\hline
\end{tabular}

Abbreviations: $\mathrm{Cl}$ = confidence interval; e-cigarettes = electronic cigarettes.

* Ever use of e-cigarettes was determined by asking, “Have you ever used an e-cigarette, even once or twice?” Ever use of cigarettes was determined by asking, “Have you ever tried cigarette smoking, even one or two puffs?" Ever use of cigars was determined by asking, "Have you ever tried smoking cigars, cigarillos, or little cigars, such as Swisher Sweets, Black and Mild, Garcia y Vega, Cheyenne, White Owl, or Dutch Masters, even one or two puffs?" Smokeless tobacco was defined as use of chewing tobacco, snuff, dip, snus, or dissolvable tobacco products. Ever use of smokeless tobacco was determined by asking the following question for use of chewing tobacco, snuff, and dip: "Have you ever used chewing tobacco, snuff, or dip, such as Copenhagen, Grizzly, Skoal, or Longhorn, even just a small amount?" and the following question for use of snus and dissolvable tobacco products: "Which of the following tobacco products have you ever tried, even just one time?" Responses from these questions were combined to derive overall smokeless tobacco use. Ever use of hookahs was determined by asking, "Have you ever tried smoking tobacco in a hookah or water pipe, even one or two puffs?" Ever use of pipe tobacco (not hookahs) was determined by asking, "Which of the following tobacco products have you ever tried, even just one time?" Because of missing data on the ever use questions, denominators for each tobacco product might be different.

${ }^{\dagger}$ Hispanic persons could be of any race.

$\S$ Estimated weighted total number of ever tobacco product users was rounded down to the nearest 10,000 persons. Overall estimates were reported among 19,018 U.S. middle and high school students. School level was determined by self-reported grade level: high school (grades $9-12 ; n=10,097$ ) and middle school (grades 6-8; $\mathrm{n}=8,837)$. Overall estimates might not directly total to sums of corresponding subgroup estimates because of rounding or inclusion of students who did not selfreport sex, race/ethnicity, or grade level.

" Data were statistically unreliable because of unweighted denominator $<50$ or a relative standard error $>30 \%$.

** Any tobacco product use was defined as ever use of any tobacco product (e-cigarettes, cigarettes, cigars, smokeless tobacco, hookahs, pipe tobacco, or bidis [small brown cigarettes wrapped in a leaf]), even just one time.

${ }^{t+}$ Any combustible tobacco product use was defined as ever use of cigarettes, cigars, hookahs, pipe tobacco, or bidis.

$\S \S$ Defined as ever use of two or more tobacco products (e-cigarettes, cigarettes, cigars, smokeless tobacco, hookahs, pipe tobacco, or bidis). 
TABLE 2. Percentage of middle and high school students who reported current (past 30-day) tobacco product use, by product, ${ }^{*}$ school level, sex, and race/ethnicity - National Youth Tobacco Survey, United States, 2019

\begin{tabular}{|c|c|c|c|c|c|c|c|c|}
\hline \multirow[b]{3}{*}{ Tobacco product } & \multicolumn{2}{|c|}{ Sex } & \multicolumn{4}{|c|}{ Race/Ethnicity } & & \\
\hline & Female & Male & $\begin{array}{c}\text { White, } \\
\text { non-Hispanic } \\
\end{array}$ & $\begin{array}{c}\text { Black, } \\
\text { non-Hispanic } \\
\end{array}$ & Hispanic $^{\dagger}$ & $\begin{array}{c}\text { Other, } \\
\text { non-Hispanic } \\
\end{array}$ & \multicolumn{2}{|c|}{ Total } \\
\hline & $\%(95 \% \mathrm{Cl})$ & $\%(95 \% \mathrm{Cl})$ & $\%(95 \% \mathrm{Cl})$ & $\%(95 \% \mathrm{Cl})$ & $\%(95 \% \mathrm{Cl})$ & $\%(95 \% \mathrm{Cl})$ & $\%(95 \% \mathrm{Cl})$ & $\begin{array}{c}\text { Estimated } \\
\text { weighted } \\
\text { no. } \S\end{array}$ \\
\hline \multicolumn{9}{|l|}{ Overall } \\
\hline E-cigarettes & $20.0(18.3-21.8)$ & $20.1(18.5-21.9)$ & $23.1(21.1-25.1)$ & $13.6(11.5-16.1)$ & $18.7(16.9-20.7)$ & $13.6(10.9-16.9)$ & $20.0(18.6-21.6)$ & $5,380,000$ \\
\hline Cigars & $4.3(3.7-5.1)$ & $6.3(5.4-7.2)$ & $5.1(4.3-6.1)$ & $8.6(7.0-10.6)$ & $4.8(3.9-5.9)$ & -9 & $5.3(4.6-6.1)$ & $1,430,000$ \\
\hline Cigarettes & $3.4(2.7-4.1)$ & $5.1(4.0-6.4)$ & $5.0(3.9-6.4)$ & $3.1(2.3-4.1)$ & $3.6(2.8-4.5)$ & - & $4.3(3.5-5.2)$ & $1,150,000$ \\
\hline Smokeless tobacco & $1.4(1.0-1.9)$ & $5.5(4.4-6.9)$ & $4.5(3.4-6.0)$ & - & $2.4(1.9-3.0)$ & - & $3.5(2.8-4.4)$ & 940,000 \\
\hline Hookahs & $2.6(2.1-3.2)$ & $2.6(2.0-3.3)$ & $1.9(1.4-2.5)$ & $4.5(3.3-6.1)$ & $3.3(2.5-4.4)$ & - & $2.6(2.1-3.1)$ & 690,000 \\
\hline Pipe tobacco & - & $1.1(0.8-1.6)$ & $0.9(0.6-1.4)$ & - & - & - & $0.8(0.6-1.1)$ & 210,000 \\
\hline Any tobacco product ${ }^{* *}$ & $22.5(20.8-24.3)$ & $23.5(21.6-25.4)$ & $25.3(23.2-27.6)$ & $19.6(17.0-22.4)$ & $22.0(20.1-24.0)$ & $15.3(12.3-18.9)$ & $23.0(21.4-24.6)$ & $6,200,000$ \\
\hline $\begin{array}{l}\text { Any combustible } \\
\text { tobacco product }\end{array}$ & $7.8(6.9-8.8)$ & $9.8(8.5-11.2)$ & $8.5(7.2-10.0)$ & $12.0(10.1-14.3)$ & $8.8(7.7-9.9)$ & $5.5(3.9-7.8)$ & $8.8(7.8-9.9)$ & $2,380,000$ \\
\hline $\begin{array}{l}\text { Two or more tobacco } \\
\text { products } \$ \S\end{array}$ & $6.1(5.4-6.9)$ & $9.4(8.2-10.9)$ & $8.5(7.2-10.1)$ & $8.2(6.6-10.0)$ & $6.9(6.1-7.8)$ & $5.0(3.7-6.7)$ & $7.8(6.9-8.9)$ & $2,110,000$ \\
\hline \multicolumn{9}{|l|}{ High school } \\
\hline E-cigarettes & $27.4(25.0-29.9)$ & $27.6(25.1-30.3)$ & $32.4(29.8-35.2)$ & $17.7(14.5-21.4)$ & $23.2(20.6-26.0)$ & $18.6(14.6-23.3)$ & $27.5(25.3-29.7)$ & $4,110,000$ \\
\hline Cigars & $6.2(5.2-7.3)$ & $9.0(7.7-10.5)$ & $7.6(6.2-9.3)$ & $12.3(10.2-14.7)$ & $6.2(5.0-7.6)$ & - & $7.6(6.6-8.8)$ & $1,140,000$ \\
\hline Cigarettes & $4.1(3.1-5.4)$ & $7.3(5.7-9.4)$ & $7.1(5.4-9.2)$ & - & $3.8(2.9-5.0)$ & - & $5.8(4.6-7.3)$ & 860,000 \\
\hline Smokeless tobacco & $1.8(1.2-2.7)$ & $7.5(5.8-9.8)$ & $6.5(4.8-8.8)$ & - & $2.6(2.0-3.5)$ & - & $4.8(3.7-6.3)$ & 720,000 \\
\hline Hookahs & $3.2(2.5-4.1)$ & $3.6(2.7-4.6)$ & $2.5(1.8-3.3)$ & $6.4(4.7-8.7)$ & $4.0(3.0-5.5)$ & - & $3.4(2.7-4.2)$ & 500,000 \\
\hline Pipe tobacco & -- & $1.5(1.0-2.3)$ & $1.3(0.8-2.0)$ & - & - & - & $1.1(0.8-1.5)$ & 160,000 \\
\hline Any tobacco product & $30.6(28.4-33.0)$ & $31.8(29.1-34.6)$ & $35.6(32.7-38.6)$ & $25.4(22.2-28.9)$ & $26.6(24.1-29.2)$ & $20.7(16.4-25.7)$ & $31.2(29.1-33.5)$ & $4,690,000$ \\
\hline $\begin{array}{l}\text { Any combustible } \\
\text { tobacco product }\end{array}$ & $10.2(8.8-11.7)$ & $13.6(11.7-15.8)$ & $11.9(10.0-14.2)$ & $16.8(14.4-19.5)$ & $10.3(8.9-11.9)$ & $7.3(4.8-11.0)$ & $12.0(10.6-13.6)$ & $1,800,000$ \\
\hline $\begin{array}{l}\text { Two or more tobacco } \\
\text { products }\end{array}$ & $8.0(6.9-9.3)$ & $13.4(11.4-15.6)$ & $12.0(10.0-14.4)$ & $11.5(9.4-14.1)$ & $8.5(7.3-9.8)$ & - & $10.8(9.4-12.4)$ & $1,620,000$ \\
\hline \multicolumn{9}{|l|}{ Middle school } \\
\hline E-cigarettes & $10.8(9.4-12.4)$ & $10.2(8.8-11.9)$ & $10.3(8.8-12.0)$ & $8.6(6.6-11.1)$ & $13.1(11.2-15.3)$ & - & $10.5(9.4-11.8)$ & $1,240,000$ \\
\hline Cigars & $2.0(1.4-2.8)$ & $2.7(2.1-3.4)$ & $1.8(1.2-2.5)$ & - & $3.1(2.2-4.3)$ & - & $2.3(1.9-2.9)$ & 270,000 \\
\hline Cigarettes & $2.5(1.8-3.4)$ & $2.1(1.6-2.7)$ & $2.1(1.5-3.1)$ & - & $3.1(2.2-4.3)$ & - & $2.3(1.8-2.9)$ & 270,000 \\
\hline Smokeless tobacco & - & $2.7(2.1-3.5)$ & $1.9(1.4-2.7)$ & - & - & - & $1.8(1.4-2.2)$ & 210,000 \\
\hline Hookahs & $1.8(1.2-2.6)$ & $1.3(1.0-1.8)$ & - & - & $2.4(1.6-3.7)$ & - & $1.6(1.2-2.1)$ & 180,000 \\
\hline Pipe tobacco & - & - & - & - & - & - & - & - \\
\hline Any tobacco product & $12.4(10.8-14.1)$ & $12.5(10.9-14.3)$ & $11.4(9.8-13.2)$ & $12.3(10.0-15.0)$ & $16.1(14.1-18.4)$ & - & $12.5(11.2-13.9)$ & $1,470,000$ \\
\hline $\begin{array}{l}\text { Any combustible } \\
\text { tobacco product }\end{array}$ & $4.9(3.8-6.2)$ & $4.6(3.9-5.5)$ & $3.8(3.0-4.9)$ & $6.1(4.5-8.1)$ & $6.6(5.4-8.1)$ & - & $4.8(4.0-5.7)$ & 560,000 \\
\hline $\begin{array}{l}\text { Two or more tobacco } \\
\text { products }\end{array}$ & $3.7(2.9-4.7)$ & $4.2(3.5-5.1)$ & $3.8(2.9-5.0)$ & $3.9(3.0-5.1)$ & $5.0(4.0-6.2)$ & - & $4.0(3.3-4.7)$ & 470,000 \\
\hline
\end{tabular}

Abbreviations: $\mathrm{Cl}=$ confidence interval; e-cigarettes = electronic cigarettes.

* Past 30-day use of e-cigarettes was determined by asking, “During the past 30 days, on how many days did you use e-cigarettes?" Past 30-day use of cigarettes was determined by asking, "During the past 30 days, on how many days did you smoke cigarettes?" Past 30-day use of cigars was determined by asking, "During the past 30 days, on how many days did you smoke cigars, cigarillos, or little cigars?" Smokeless tobacco was defined as use of chewing tobacco, snuff, dip, snus, or dissolvable tobacco products. Past 30-day use of smokeless tobacco was determined by asking the following question for use of chewing tobacco, snuff, and dip: "During the past 30 days, on how many days did you use chewing tobacco, snuff, or dip?" and the following question for use of snus and dissolvable tobacco products: "In the past 30 days, which of the following products did you use on at least one day?" Responses from these questions were combined to derive overall smokeless tobacco use. Past 30-day use of hookahs was determined by asking, "During the past 30 days, on how many days did you smoke tobacco in a hookah or water pipe?" Past 30-day use of pipe tobacco (not hookahs) was determined by asking, "In the past 30 days, which of the following products have you used on at least one day?" Because of missing data on the past 30-day use questions, denominators for each tobacco product might be different.

† Hispanic persons could be of any race.

$\S$ Estimated weighted total number of current tobacco product users was rounded down to the nearest 10,000 persons. Overall estimates were reported among $19,018$ U.S. middle and high school students. School level was determined by self-reported grade level: high school (grades $9-12 ; n=10,097)$ and middle school (grades $6-8 ; n=8,837$ ). Overall estimates might not directly total to sums of corresponding subgroup estimates because of rounding or inclusion of students who did not self-report sex, race/ethnicity, or grade level.

" Data were statistically unreliable because of unweighted denominator $<50$ or a relative standard error $>30 \%$.

** Any tobacco product use was defined as use of any tobacco product (e-cigarettes, cigarettes, cigars, smokeless tobacco, hookahs, pipe tobacco, or bidis [small brown cigarettes wrapped in a leaf]) on $\geq 1$ day during the past 30 days.

t+ Any combustible tobacco product use was defined as use of cigarettes, cigars, hookahs, pipe tobacco, or bidis on $\geq 1$ day during the past 30 days.

$\S \S$ Defined as use of two or more tobacco products (e-cigarettes, cigarettes, cigars, smokeless tobacco, hookahs, pipe tobacco, or bidis) on $\geq 1$ day during the past 30 days. 
TABLE 3. Frequency of use* among middle and high school students currently using cigarettes, e-cigarettes, cigars, smokeless tobacco, and hookahs - National Youth Tobacco Survey, United States, 2019

\begin{tabular}{|c|c|c|c|c|c|c|c|c|c|c|}
\hline \multirow[b]{2}{*}{ Days of use } & \multicolumn{2}{|c|}{ E-cigarettes } & \multicolumn{2}{|c|}{ Cigarettes } & \multicolumn{2}{|l|}{ Cigars } & \multicolumn{2}{|c|}{ Smokeless tobacco } & \multicolumn{2}{|l|}{ Hookahs } \\
\hline & $\%(95 \% \mathrm{Cl})^{\dagger}$ & $\begin{array}{c}\text { Estimated } \\
\text { no. } \S\end{array}$ & $\%(95 \% \mathrm{Cl})$ & $\begin{array}{c}\text { Estimated } \\
\text { no. }\end{array}$ & $\%(95 \% \mathrm{Cl})$ & $\begin{array}{c}\text { Estimated } \\
\text { no. }\end{array}$ & $\%(95 \% \mathrm{Cl})$ & $\begin{array}{c}\text { Estimated } \\
\text { no. }\end{array}$ & $\%(95 \% \mathrm{Cl})$ & $\begin{array}{c}\text { Estimated } \\
\text { weighted } \\
\text { no. }\end{array}$ \\
\hline \multicolumn{11}{|l|}{ Overall" } \\
\hline $1-5$ & $50.8(48.1-53.4)$ & $2,730,000$ & $55.9(49.6-62.1)$ & 640,000 & $68.7(63.9-73.1)$ & 980,000 & $49.3(43.3-55.4)$ & 390,000 & $69.1(62.8-74.7)$ & 480,000 \\
\hline $6-19$ & $18.8(17.5-20.3)$ & $1,010,000$ & $15.2(12.3-18.7)$ & 170,000 & $14.5(12.0-17.5)$ & 200,000 & $16.6(12.7-21.4)$ & 130,000 & $12.4(8.8-17.3)$ & 80,000 \\
\hline $20-30$ & $30.4(27.7-33.3)$ & $1,630,000$ & $28.9(23.1-35.5)$ & 330,000 & $16.8(12.7-21.9)$ & 240,000 & $34.1(28.2-40.5)$ & 270,000 & $18.6(13.1-25.6)$ & 120,000 \\
\hline \multicolumn{11}{|c|}{ High school** } \\
\hline $1-5$ & $46.4(43.6-49.3)$ & $1,910,000$ & $51.5(44.2-58.7)$ & 440,000 & $68.6(63.5-73.3)$ & 780,000 & $44.0(37.1-51.2)$ & 270,000 & $69.2(61.7-75.8)$ & 350,000 \\
\hline $6-19$ & $19.4(17.8-21.1)$ & 790,000 & $16.0(12.3-20.6)$ & 130,000 & $14.1(11.4-17.4)$ & 160,000 & $18.0(13.7-23.4)$ & 110,000 & $13.2(8.6-19.6)$ & ) 60,000 \\
\hline $20-30$ & $34.2(31.2-37.3)$ & $1,400,000$ & $32.5(25.3-40.5)$ & 280,000 & $17.3(13.0-22.7)$ & 190,000 & $37.9(30.3-46.2)$ & 230,000 & $17.6(12.0-25.1)$ & 80,000 \\
\hline \multicolumn{11}{|c|}{ Middle school ${ }^{\dagger \dagger}$} \\
\hline $1-5$ & $65.3(61.0-69.5)$ & 810,000 & $70.1(62.2-76.9)$ & 190,000 & $69.0(58.3-78.0)$ & 190,000 & $66.0(54.5-75.9)$ & 110,000 & $68.1(58.8-76.1)$ & ) 120,000 \\
\hline $6-19$ & $16.7(13.5-20.4)$ & 200,000 & —§§ & - & - & - & - & - & - & - \\
\hline $20-30$ & $18.0(15.2-21.2)$ & 220,000 & - & - & - & - & - & - & - & - \\
\hline
\end{tabular}

Abbreviations: $\mathrm{Cl}=$ confidence interval; e-cigarettes = electronic cigarettes.

* Frequency of current use of e-cigarettes, cigarettes, cigars (defined as cigars, cigarillos, or little cigars), smokeless tobacco (defined as chewing tobacco, snuff, or dip; frequency of use was not assessed for snus or dissolvable tobacco products), and hookahs was determined by asking participants on how many days they smoked or used each of these tobacco products during the past 30 days. Respondents could enter a valid response of 0-30 days.

${ }^{\dagger}$ Reported among respective current (past 30-day) users for each product. Past 30-day use of e-cigarettes was determined by asking, "During the past 30 days, on how many days did you use e-cigarettes?" Past 30-day use of cigarettes was determined by asking, "During the past 30 days, on how many days did you smoke cigarettes?" Past 30-day use of cigars was determined by asking, "During the past 30 days, on how many days did you smoke cigars, cigarillos, or little cigars?" Past 30-day use of smokeless tobacco was determined by asking the following question for use of chewing tobacco, snuff, and dip: "During the past 30 days, on how many days did you use chewing tobacco, snuff, or dip?" Past 30-day use of hookahs was determined by asking, "During the past 30 days, on how many days did you smoke tobacco in a hookah or water pipe?"

$\S$ Estimated weighted total number of users was rounded down to the nearest 10,000 persons. Overall estimates might not directly total to sums of corresponding subgroup estimates because of rounding or inclusion of students who did not self-report grade level.

I Calculated among total current users of e-cigarettes $(n=3,628)$, cigarettes $(n=748)$, cigars $(n=930)$, smokeless tobacco $(n=531)$, and hookahs ( $n=477)$.

** Calculated among current high school tobacco product users (self-reported grades 9-12) of e-cigarettes $(n=2,709)$, cigarettes $(n=549)$, cigars ( $n=727)$, smokeless tobacco $(n=399)$, and hookahs $(n=334)$.

${ }^{+\dagger}$ Calculated among current middle school tobacco product users (self-reported grades $\left.6-8\right)$ of e-cigarettes $(n=902)$, cigarettes $(n=190)$, cigars $(n=197)$, smokeless tobacco $(n=125)$, and hookahs $(n=138)$.

$\S \S$ Data were statistically unreliable because of unweighted denominator $<50$ or a relative standard error $>30 \%$. 
TABLE 4. Flavored tobacco product* use among all middle and high school students and among those who reported current use ${ }^{\dagger}$ of specified tobacco products, by school level, sex, and race/ethnicity — National Youth Tobacco Survey, United States, 2019

\begin{tabular}{|c|c|c|c|c|c|c|c|}
\hline \multirow[b]{3}{*}{ Charactorictis } & \multicolumn{7}{|c|}{ Tobacco product } \\
\hline & $\begin{array}{c}\text { Any tobacco } \\
\text { product } \$\end{array}$ & E-cigarettes & Cigarettes" & Cigars & $\begin{array}{l}\text { Smokeless } \\
\text { tobacco*** }\end{array}$ & Hookahs & Pipe tobacco \\
\hline & $\%(95 \% \mathrm{Cl})$ & $\%(95 \% \mathrm{Cl})$ & $\%(95 \% \mathrm{Cl})$ & $\%(95 \% \mathrm{Cl})$ & $\%(95 \% \mathrm{Cl})$ & $\%(95 \% \mathrm{Cl})$ & $\%(95 \% \mathrm{Cl})$ \\
\hline \multicolumn{8}{|l|}{ Overall } \\
\hline $\begin{array}{l}\text { Flavored tobacco } \\
\text { product use among all } \\
\text { students }{ }^{\dagger \dagger}\end{array}$ & $16.0(14.6-17.4)$ & $13.8(12.5-15.1)$ & $2.0(1.6-2.5)$ & $2.2(1.9-2.6)$ & $1.7(1.3-2.2)$ & $0.8(0.6-1.1)$ & $0.3(0.2-0.4)$ \\
\hline \multicolumn{8}{|c|}{ Current tobacco product users } \\
\hline $\begin{array}{l}\text { Estimated weighted no. } \\
\text { of flavored tobacco } \\
\text { product users }{ }^{\S \S}\end{array}$ & $4,310,000$ & $3,700,000$ & 530,000 & 600,000 & 450,000 & 210,000 & 60,000 \\
\hline $\begin{array}{l}\text { Flavored tobacco } \\
\text { product use among } \\
\text { current tobacco } \\
\text { product users }\end{array}$ & $69.6(67.0-72.0)$ & $68.8(66.2-71.4)$ & $46.7(42.5-51.0)$ & $41.9(38.0-46.0)$ & $48.0(42.8-53.2)$ & $31.2(25.7-37.3)$ & $31.4(23.1-41.1)$ \\
\hline \multicolumn{8}{|l|}{ School level } \\
\hline High school & $72.8(69.7-75.6)$ & $71.7(68.6-74.5)$ & $49.8(44.8-54.8)$ & $43.2(39.1-47.4)$ & $49.8(43.5-56.2)$ & $32.9(26.3-40.1)$ & $28.0(19.9-37.7)$ \\
\hline \multicolumn{8}{|l|}{ Sex } \\
\hline Female & $68.6(64.9-72.1)$ & $68.3(64.5-71.9)$ & $49.7(43.1-56.2)$ & $38.6(32.9-44.5)$ & $36.4(26.9-47.0)$ & $34.7(26.3-44.2)$ & - \\
\hline Male & $70.7(68.1-73.1)$ & $69.6(66.9-72.3)$ & $45.1(38.9-51.5)$ & $44.2(39.3-49.1)$ & $50.9(44.6-57.2)$ & $27.2(19.4-36.7)$ & $36.2(27.3-46.1)$ \\
\hline \multicolumn{8}{|l|}{ Race/Ethnicity } \\
\hline White, non-Hispanic & $76.8(74.6-78.9)$ & $75.2(72.6-77.6)$ & $45.8(40.4-51.4)$ & $44.2(37.5-51.2)$ & $55.8(49.7-61.7)$ & $32.1(23.0-42.9)$ & $31.0(18.9-46.3)$ \\
\hline Black, non-Hispanic & $48.0(41.9-54.1)$ & $43.1(35.9-50.7)$ & $39.6(25.6-55.6)$ & $41.2(33.7-49.2)$ & - & $24.5(14.0-39.4)$ & - \\
\hline Hispanic ${ }^{\dagger+\dagger}$ & $63.1(59.0-67.1)$ & $63.0(58.5-67.2)$ & $50.8(42.7-58.8)$ & $36.5(30.2-43.3)$ & $29.4(21.1-39.5)$ & $35.6(25.3-47.5)$ & $46.5(30.5-63.2)$ \\
\hline Other, non-Hispanic & $68.1(61.6-74.0)$ & $68.7(61.3-75.2)$ & $47.4(34.8-60.2)$ & $43.7(33.8-54.1)$ & $40.1(27.2-54.5)$ & $27.4(15.8-43.2)$ & - \\
\hline
\end{tabular}

Abbreviations: $\mathrm{Cl}=$ confidence interval; e-cigarettes = electronic cigarettes.

* Flavored tobacco product use was determined by the response to the question, "Which of the following tobacco products that you used in the past 30 days were flavored to taste like menthol (mint), alcohol (wine, cognac), candy, fruit, chocolate, or other sweets?" Participants could select from a list of options to designate the flavored tobacco products they had used. Among those who reported any use of each respective product during the past 30 days, those who selected the flavored product were categorized as flavored product users, those who did not select the flavored product were categorized as only nonflavored product users, and those who did not provide any response to the flavored product use question were assigned as missing flavor status.

† Current (past 30-day) use of e-cigarettes was determined by asking, "During the past 30 days, on how many days did you use e-cigarettes?" Current use of cigarettes was determined by asking, "During the past 30 days, on how many days did you smoke cigarettes?" Current use of cigars was determined by asking, "During the past 30 days, on how many days did you smoke cigars, cigarillos, or little cigars?" Smokeless tobacco was defined as use of chewing tobacco, snuff, dip, snus, or dissolvable tobacco products. Current use of smokeless tobacco was determined by asking the following question for use of chewing tobacco, snuff, and dip: "During the past 30 days, on how many days did you use chewing tobacco, snuff, or dip?" and the following question for use of snus and dissolvable tobacco products: "In the past 30 days, which of the following products did you use on at least one day?" Responses from these questions were combined to derive overall smokeless tobacco use. Current use of hookahs was determined by asking, "During the past 30 days, on how many days did you smoke tobacco in a hookah or water pipe?" Current use of pipe tobacco (not hookahs) was determined by asking, "In the past 30 days, which of the following products have you used on at least one day?"

$\S$ Any current tobacco product use was defined as use of any tobacco product (e-cigarettes, cigarettes, cigars, smokeless tobacco, hookahs, pipe tobacco, or bidis [small brown cigarettes wrapped in a leaf]) on $\geq 1$ day during the past 30 days.

I Flavored cigarette use referred to menthol cigarettes. Menthol cigarette status was determined by asking, "Menthol cigarettes are cigarettes that taste like mint. During the past 30 days, were the cigarettes that you usually smoked menthol?" and "During the past 30 days, what brand or cigarettes did you usually smoke?" Among past 30-day cigarette smokers, those responding "yes" to the menthol question or who reported "Newport" or "Kool" as the usual cigarette brand were categorized as menthol cigarette smokers; subsequently, those who reported "no" to the menthol question and who did not report "Newport" or "Kool" brands were categorized as nonmenthol cigarette smokers; all other past 30-day cigarette smokers were assigned as missing menthol cigarette smoking status.

** Any smokeless tobacco was current use of smokeless tobacco (chewing tobacco, snuff, dip, snus, or dissolvable tobacco products) on $\geq 1$ day during the past 30 days.

${ }^{+\dagger}$ Calculated among all respondents regardless of tobacco product use status. Because of missing data, denominators for each tobacco product might be different: e-cigarettes $(n=18,914)$, cigarettes $(n=18,975)$, cigars $(n=18,958)$, smokeless tobacco $(n=19,018)$, hookahs $(n=18,948)$, and pipe tobacco $(n=18,821)$.

$\S \S$ Estimated weighted total number of flavored tobacco product users was rounded down to the nearest 10,000 persons.

१ศ Calculated among current users of any tobacco product $(n=4,198)$, e-cigarettes $(n=3,628)$, cigarettes $(n=748)$, cigars $(n=930)$, smokeless tobacco $(n=630)$, hookahs $(n=477)$, and pipe tobacco $(n=138)$.

*** Data were statistically unreliable because of unweighted denominator $<50$ or a relative standard error $>30 \%$.

${ }^{t+\dagger}$ Hispanic persons could be of any race. 
TABLE 5. Reasons for e-cigarette use* among middle and high school students who reported ever using e-cigarettes, ${ }^{\dagger}$ by school level, sex, and race/ethnicity - National Youth Tobacco Survey, United States, 2019

\begin{tabular}{|c|c|c|c|c|c|c|c|c|c|c|}
\hline \multirow[b]{3}{*}{ Reason } & & & \multicolumn{2}{|c|}{ School level } & \multicolumn{2}{|c|}{ Sex } & \multicolumn{4}{|c|}{ Race/Ethnicity } \\
\hline & \multicolumn{2}{|c|}{ Overall } & \multirow{2}{*}{$\frac{\begin{array}{c}\text { Middle } \\
\text { school }\end{array}}{\%(95 \% \mathrm{Cl})}$} & \multirow{2}{*}{$\begin{array}{c}\begin{array}{c}\text { High } \\
\text { school }\end{array} \\
\%(95 \% \mathrm{Cl})\end{array}$} & \multirow{2}{*}{$\frac{\text { Male }}{\%(95 \% \mathrm{Cl})}$} & \multirow{2}{*}{$\frac{\text { Female }}{\%(95 \% \mathrm{Cl})}$} & \multirow{2}{*}{$\begin{array}{c}\begin{array}{c}\text { White, } \\
\text { non- } \\
\text { Hispanic }\end{array} \\
\%(95 \% \mathrm{Cl})\end{array}$} & \multirow{2}{*}{$\begin{array}{c}\begin{array}{c}\text { Black, } \\
\text { non- } \\
\text { Hispanic }\end{array} \\
\%(95 \% \mathrm{Cl})\end{array}$} & \multirow{2}{*}{$\frac{\text { Hispanic }}{\%(95 \% \mathrm{Cl})}$} & \multirow{2}{*}{$\begin{array}{c}\text { Other, } \\
\text { non-Hispanic } \\
\%(95 \% \mathrm{Cl})\end{array}$} \\
\hline & $\%(95 \% \mathrm{Cl})$ & Estimated no. ${ }^{\S}$ & & & & & & & & \\
\hline $\begin{array}{l}\text { I was curious about } \\
\text { them }\end{array}$ & $\begin{array}{r}55.3 \\
(53.3-57.3)\end{array}$ & $5,110,000$ & $\begin{array}{r}57.1 \\
(54.5-59.8)\end{array}$ & $\begin{array}{r}54.8 \\
(52.5-57.0)\end{array}$ & $\begin{array}{r}52.1 \\
(49.3-54.9)\end{array}$ & $\begin{array}{r}58.9 \\
(56.8-61.0)\end{array}$ & $\begin{array}{r}53.1 \\
(50.5-55.6)\end{array}$ & $\begin{array}{r}53.7 \\
(48.8-58.5)\end{array}$ & $\begin{array}{r}61.5 \\
(58.6-64.4)\end{array}$ & $\begin{array}{r}56.4 \\
(48.7-64.0)\end{array}$ \\
\hline $\begin{array}{l}\text { Friend or family } \\
\text { member used them }\end{array}$ & $\begin{array}{r}30.8 \\
(29.1-32.6)\end{array}$ & $2,850,000$ & $\begin{array}{r}36.8 \\
(33.7-40.0)\end{array}$ & $\begin{array}{r}28.9 \\
(26.8-31.0)\end{array}$ & $\begin{array}{r}27.1 \\
(24.6-29.7)\end{array}$ & $\begin{array}{r}34.9 \\
(32.9-37.0)\end{array}$ & $\begin{array}{r}31.8 \\
(29.6-34.1)\end{array}$ & $\begin{array}{r}30.8 \\
(26.3-35.7)\end{array}$ & $\begin{array}{r}28.1 \\
(25.6-30.7)\end{array}$ & $\begin{array}{r}29.1 \\
(21.3-38.3)\end{array}$ \\
\hline $\begin{array}{l}\text { They are available in } \\
\text { flavors, such as mint, } \\
\text { candy, fruit, or } \\
\text { chocolate }\end{array}$ & $\begin{array}{r}22.4 \\
(20.8-24.1)\end{array}$ & $2,070,000$ & $\begin{array}{r}22.8 \\
(20.5-25.2)\end{array}$ & $\begin{array}{r}22.3 \\
(20.4-24.3)\end{array}$ & $\begin{array}{r}20.7 \\
(17.9-23.8)\end{array}$ & $\begin{array}{r}24.3 \\
(22.4-26.3)\end{array}$ & $\begin{array}{r}22.8 \\
(21.0-24.8)\end{array}$ & $\begin{array}{r}21.7 \\
(18.4-25.4)\end{array}$ & $\begin{array}{r}22.4 \\
(19.7-25.3)\end{array}$ & $\begin{array}{r}19.1 \\
(14.0-25.5)\end{array}$ \\
\hline $\begin{array}{l}\text { I can use them to do } \\
\text { tricks }\end{array}$ & $\begin{array}{r}21.2 \\
(19.5-23.0)\end{array}$ & $1,960,000$ & $\begin{array}{r}22.6 \\
(20.7-24.6)\end{array}$ & $\begin{array}{r}20.8 \\
(18.5-23.1)\end{array}$ & $\begin{array}{r}23.3 \\
(20.3-26.5)\end{array}$ & $\begin{array}{r}19.0 \\
(17.2-20.8)\end{array}$ & $\begin{array}{r}21.6 \\
(19.8-23.6)\end{array}$ & $\begin{array}{r}18.9 \\
(15.3-23.2)\end{array}$ & $\begin{array}{r}21.1 \\
(18.3-24.2)\end{array}$ & $\begin{array}{r}22.1 \\
(15.7-30.2)\end{array}$ \\
\hline $\begin{array}{l}\text { They are less harmful } \\
\text { than other forms of } \\
\text { tobacco, such as } \\
\text { cigarettes }\end{array}$ & $\begin{array}{r}15.7 \\
(14.3-17.2)\end{array}$ & $1,450,000$ & $\begin{array}{r}15.8 \\
(14.0-17.7)\end{array}$ & $\begin{array}{r}15.6 \\
(13.9-17.5)\end{array}$ & $\begin{array}{r}17.5 \\
(15.4-19.7)\end{array}$ & $\begin{array}{r}13.6 \\
(12.0-15.4)\end{array}$ & $\begin{array}{r}16.4 \\
(14.7-18.2)\end{array}$ & $\begin{array}{r}13.0 \\
(9.6-17.2)\end{array}$ & $\begin{array}{r}15.6 \\
(13.3-18.1)\end{array}$ & —** \\
\hline $\begin{array}{l}\text { I can use them } \\
\text { unnoticed at home } \\
\text { or at school }\end{array}$ & $\begin{array}{r}13.9 \\
(11.4-16.8)\end{array}$ & $1,280,000$ & $\begin{array}{r}10.5 \\
(8.6-12.7)\end{array}$ & $\begin{array}{r}14.9 \\
(11.8-18.6)\end{array}$ & $\begin{array}{r}14.6 \\
(10.3-20.2)\end{array}$ & $\begin{array}{r}13.1 \\
(11.7-14.6)\end{array}$ & $\begin{array}{r}14.4 \\
(12.1-17.0)\end{array}$ & $\begin{array}{r}8.0 \\
(5.3-11.9)\end{array}$ & $\begin{array}{r}14.8 \\
(11.0-19.6)\end{array}$ & - \\
\hline $\begin{array}{l}\text { I was peer pressured } \\
\text { into using them }\end{array}$ & $\begin{array}{r}10.7 \\
(9.5-12.1)\end{array}$ & 990,000 & $\begin{array}{r}11.1 \\
(8.9-13.7)\end{array}$ & $\begin{array}{r}10.6 \\
(9.2-12.2)\end{array}$ & $\begin{array}{r}10.7 \\
(9.0-12.7)\end{array}$ & $\begin{array}{r}10.8 \\
(9.2-12.6)\end{array}$ & $\begin{array}{r}11.8 \\
(10.1-13.7)\end{array}$ & $\begin{array}{r}8.7 \\
(6.5-11.6)\end{array}$ & $\begin{array}{r}8.8 \\
(6.9-11.0)\end{array}$ & - \\
\hline $\begin{array}{l}\text { To try to quit using } \\
\text { other tobacco } \\
\text { products, such as } \\
\text { cigarettes }\end{array}$ & $\begin{array}{r}5.5 \\
(4.5-6.7)\end{array}$ & 500,000 & - & $\begin{array}{r}6.4 \\
(5.1-7.9)\end{array}$ & $\begin{array}{r}7.0 \\
(5.7-8.5)\end{array}$ & $\begin{array}{r}3.7 \\
(2.7-5.2)\end{array}$ & $\begin{array}{r}6.6 \\
(5.2-8.4)\end{array}$ & - & $\begin{array}{r}3.8 \\
(2.9-5.0)\end{array}$ & - \\
\hline $\begin{array}{l}\text { They are easier to get } \\
\text { than other tobacco } \\
\text { products, such as } \\
\text { cigarettes }\end{array}$ & $\begin{array}{r}5.4 \\
(4.1-7.0)\end{array}$ & 500,000 & $\begin{array}{r}5.0 \\
(3.8-6.5)\end{array}$ & $\begin{array}{r}5.5 \\
(4.0-7.5)\end{array}$ & $\begin{array}{r}6.5 \\
(4.5-9.4)\end{array}$ & $4.1(3.3-5.1)$ & $\begin{array}{r}5.8 \\
(4.2-8.0)\end{array}$ & - & $\begin{array}{r}4.6 \\
(3.7-5.6)\end{array}$ & - \\
\hline $\begin{array}{l}\text { I've seen people on } \\
\text { TV, online, or in } \\
\text { movies use them }\end{array}$ & $\begin{array}{r}4.4 \\
(3.8-5.0)\end{array}$ & 400,000 & $\begin{array}{r}6.3 \\
(5.1-7.9)\end{array}$ & $\begin{array}{r}3.7 \\
(3.2-4.4)\end{array}$ & $\begin{array}{r}4.2 \\
(3.6-5.0)\end{array}$ & $\begin{array}{r}4.4 \\
(3.6-5.4)\end{array}$ & $\begin{array}{r}3.9 \\
(3.2-4.7)\end{array}$ & - & $\begin{array}{r}4.9 \\
(3.7-6.5)\end{array}$ & - \\
\hline $\begin{array}{l}\text { They cost less than } \\
\text { other tobacco } \\
\text { products, such as } \\
\text { cigarettes }\end{array}$ & $\begin{array}{r}3.8 \\
(3.1-4.8)\end{array}$ & 350,000 & - & $\begin{array}{r}4.2 \\
(3.3-5.3)\end{array}$ & $\begin{array}{r}5.2 \\
(4.0-6.7)\end{array}$ & $\begin{array}{r}2.3 \\
(1.7-3.2)\end{array}$ & $\begin{array}{r}4.6 \\
(3.5-6.1)\end{array}$ & - & - & - \\
\hline $\begin{array}{l}\text { I used them for some } \\
\text { other reason }\end{array}$ & $\begin{array}{r}14.4 \\
(12.4-16.6)\end{array}$ & $1,330,000$ & $\begin{array}{r}15.4 \\
(13.2-18.0)\end{array}$ & $\begin{array}{r}14.1 \\
(11.8-16.7)\end{array}$ & $\begin{array}{r}15.8 \\
(12.8-19.3)\end{array}$ & $\begin{array}{r}12.8 \\
(11.4-14.3)\end{array}$ & $\begin{array}{r}15.1 \\
(12.6-18.0)\end{array}$ & $\begin{array}{r}13.8 \\
(10.8-17.4)\end{array}$ & $\begin{array}{r}12.9 \\
(10.8-15.4)\end{array}$ & - \\
\hline
\end{tabular}

Abbreviations: $\mathrm{Cl}$ = confidence interval; e-cigarettes = electronic cigarettes; TV = television.

* Assessed by the question, "What are the reasons why you have used electronic cigarettes or e-cigarettes? (Check all that apply.)" Responses were not mutually exclusive.

† Assessed by the question, "Have you ever used an e-cigarette, even once or twice?"Ever users reported e-cigarette use on $\geq 1$ day during the past 30 days ( $n=6,409$ ).

$\S$ Estimated weighted total number of users was rounded down to the nearest 10,000 persons.

I Hispanic persons could be of any race.

** Data were statistically unreliable because of unweighted denominator $<50$ or a relative standard error $>30 \%$.

${ }^{+\dagger}$ Respondents could subsequently specify a reason through a write-in option $(n=642)$. 
TABLE 6. Reasons for e-cigarette use* among middle and high school students who reported using e-cigarettes and other tobacco products during the past 30 days - National Youth Tobacco Survey, United States, 2019

\begin{tabular}{|c|c|c|c|c|}
\hline \multirow[b]{2}{*}{ Reason } & \multicolumn{2}{|c|}{ Use e-cigarettes only ${ }^{\dagger}$} & \multicolumn{2}{|c|}{ Use e-cigarettes and other tobacco products } \\
\hline & $\%(95 \% \mathrm{Cl})$ & Estimated no. ${ }^{\pi}$ & $\%(95 \% \mathrm{Cl})$ & Estimated no. \\
\hline I was curious about them & $56.1(53.4-58.7)$ & $1,900,000$ & $38.4(35.1-41.7)$ & 730,000 \\
\hline Friend or family member used them & $23.9(21.7-26.3)$ & 810,000 & $22.2(19.6-25.1)$ & 420,000 \\
\hline $\begin{array}{l}\text { They are available in flavors, such as mint, candy, fruit, } \\
\text { or chocolate }\end{array}$ & $22.3(20.3-24.5)$ & 760,000 & $26.6(23.8-29.6)$ & 500,000 \\
\hline I can use them to do tricks & $22.0(20.0-24.2)$ & 740,000 & $29.0(25.6-32.7)$ & 550,000 \\
\hline $\begin{array}{l}\text { They are less harmful than other forms of tobacco, such } \\
\text { as cigarettes }\end{array}$ & $17.2(15.3-19.3)$ & 580,000 & $19.1(16.7-21.9)$ & 360,000 \\
\hline I can use them unnoticed at home or at school & $14.5(12.9-16.3)$ & 490,000 & $22.9(19.4-26.8)$ & 430,000 \\
\hline I was peer pressured into using them & $8.9(7.7-10.3)$ & 300,000 & $7.5(5.8-9.8)$ & 140,000 \\
\hline $\begin{array}{l}\text { They are easier to get than other tobacco products, such } \\
\text { as cigarettes }\end{array}$ & $3.9(3.0-5.0)$ & 130,000 & $9.7(7.9-11.8)$ & 180,000 \\
\hline I've seen people on TV, online, or in movies use them & $3.8(3.1-4.6)$ & 120,000 & $5.4(3.9-7.4)$ & 100,000 \\
\hline To try to quit using other tobacco products, such as cigarettes & $2.8(1.8-4.2)$ & 90,000 & $17.0(14.0-20.5)$ & 320,000 \\
\hline They cost less than other tobacco products, such as cigarettes & $2.5(1.9-3.3)$ & 80,000 & $11.6(9.4-14.3)$ & 220,000 \\
\hline I used them for some other reason ${ }^{* *}$ & $15.9(14.0-18.0)$ & 540,000 & $22.2(17.9-27.3)$ & 420,000 \\
\hline
\end{tabular}

Abbreviations: $\mathrm{Cl}=$ confidence interval; e-cigarettes = electronic cigarettes; TV = television.

*Assessed by the question,"What are the reasons why you have used electronic cigarettes or e-cigarettes? (Check all that apply.)" Responses were not mutually exclusive.

$\dagger$ Reported use of only e-cigarettes on $\geq 1$ day during the past 30 days $(n=2,361)$.

$\S$ Reported use of e-cigarettes and at least one other tobacco product (e-cigarettes and cigarettes, cigars, smokeless tobacco, hookahs, pipe tobacco, or bidis [small brown cigarettes wrapped in a leaf]) on $\geq 1$ day during the past 30 days $(n=1,267)$.

" Estimated weighted total number of users was rounded down to the nearest 10,000 persons.

** Respondents could subsequently specify a reason through a write-in option $(n=465)$. 
TABLE 7. Percentage of middle and high school students who reported exposure* to sources of tobacco product marketing (advertisements or promotions), by school level, sex, and race/ethnicity - National Youth Tobacco Survey, United States, 2019

\begin{tabular}{|c|c|c|c|c|c|}
\hline & Retail stores $^{\dagger}$ & Internet ${ }^{\S}$ & $\begin{array}{l}\text { TV, streaming services, } \\
\text { or movies }\end{array}$ & $\begin{array}{l}\text { Newspapers or } \\
\text { magazines** }\end{array}$ & Any source ${ }^{t+}$ \\
\hline Characteristic & $\%(95 \% \mathrm{Cl})$ & $\%(95 \% \mathrm{Cl})$ & $\%(95 \% \mathrm{Cl})$ & $\%(95 \% \mathrm{Cl})$ & $\%(95 \% \mathrm{Cl})$ \\
\hline \multicolumn{6}{|c|}{ Exposure to any tobacco product marketing } \\
\hline Overall & $79.4(78.1-80.7)$ & $59.6(58.3-60.9)$ & $36.9(35.0-38.8)$ & $53.5(51.9-55.1)$ & $86.3(85.4-87.1)$ \\
\hline Estimated no. ${ }^{\S}$ & $20,410,000$ & $15,400,000$ & $9,260,000$ & $7,490,000$ & $22,930,000$ \\
\hline \multicolumn{6}{|l|}{ Sex } \\
\hline Male & $77.7(75.9-79.3)$ & $56.3(54.2-58.5)$ & $34.2(31.7-36.8)$ & $53.0(50.5-55.5)$ & $84.4(83.0-85.7)$ \\
\hline Female & $81.2(79.7-82.7)$ & $63.1(61.6-64.5)$ & $39.6(37.7-41.6)$ & $53.9(52.1-55.8)$ & $88.3(87.3-89.3)$ \\
\hline \multicolumn{6}{|l|}{ Race/Ethnicity } \\
\hline White, non-Hispanic & $83.1(81.8-84.3)$ & $59.9(58.3-61.5)$ & $34.7(32.4-37.2)$ & $52.9(50.6-55.1)$ & $88.3(87.3-89.3)$ \\
\hline Black, non-Hispanic & $75.4(73.1-77.6)$ & $61.4(58.5-64.3)$ & $46.9(43.4-50.6)$ & $58.3(54.3-62.2)$ & $86.1(84.2-87.8)$ \\
\hline Hispanic 19 & $76.2(74.3-78.1)$ & $59.6(57.7-61.4)$ & $38.0(36.0-40.0)$ & $53.8(51.7-55.8)$ & $84.3(82.9-85.7)$ \\
\hline Other, non-Hispanic & $68.0(65.0-70.9)$ & $55.7(52.1-59.3)$ & $28.8(25.7-32.1)$ & $47.9(43.7-52.1)$ & $78.7(76.0-81.3)$ \\
\hline \multicolumn{6}{|l|}{ School level } \\
\hline Middle school & $77.3(75.4-79.1)$ & $58.2(56.6-59.7)$ & $35.0(32.8-37.3)$ & $52.9(50.7-55.2)$ & $85.2(83.9-86.4)$ \\
\hline High school & $81.2(79.7-82.6)$ & $60.8(59.2-62.4)$ & $38.4(36.1-40.7)$ & $53.9(51.8-56.0)$ & $87.3(86.2-88.3)$ \\
\hline \multicolumn{6}{|c|}{ Exposure to e-cigarette marketing ${ }^{* * *}$} \\
\hline Overall & $58.4(56.5-60.2)$ & $44.6(43.4-45.8)$ & $26.2(24.9-27.5)$ & $34.8(33.5-36.1)$ & $69.3(67.8-70.8)$ \\
\hline Estimated no. & $15,030,000$ & $11,510,000$ & $6,620,000$ & $5,070,000$ & $18,260,000$ \\
\hline \multicolumn{6}{|l|}{ Sex } \\
\hline Male & $56.6(54.4-58.7)$ & $41.2(39.5-43.0)$ & $23.9(22.2-25.7)$ & $33.3(31.2-35.5)$ & $67.3(65.4-69.2)$ \\
\hline Female & $60.3(58.1-62.4)$ & $48.1(46.4-49.8)$ & $28.5(27.0-30.2)$ & $36.4(34.7-38.0)$ & $71.5(69.6-73.2)$ \\
\hline \multicolumn{6}{|l|}{ Race/Ethnicity } \\
\hline White, non-Hispanic & $62.9(60.7-65.0)$ & $46.2(44.6-47.9)$ & $26.0(24.2-27.8)$ & $34.8(33.0-36.7)$ & $72.6(70.8-74.2)$ \\
\hline Black, non-Hispanic & $52.2(49.5-55.0)$ & $42.6(40.0-45.2)$ & $30.0(27.4-32.7)$ & $36.0(32.7-39.4)$ & $66.5(64.3-68.6)$ \\
\hline Hispanic & $54.0(51.9-56.2)$ & $43.4(41.8-45.1)$ & $26.3(24.6-28.1)$ & $35.5(33.7-37.3)$ & $66.2(64.1-68.2)$ \\
\hline Other, non-Hispanic & $48.8(44.7-52.9)$ & $41.8(38.7-45.1)$ & $19.4(17.1-21.9)$ & $31.9(28.3-35.8)$ & $62.4(58.9 .-65.7)$ \\
\hline \multicolumn{6}{|l|}{ School level } \\
\hline Middle school & $53.8(51.4-56.2)$ & $41.5(40.0-43.1)$ & $24.3(22.6-26.0)$ & $33.4(31.4-35.4)$ & $65.7(63.8-67.5)$ \\
\hline High school & $62.1(60.0-64.2)$ & $47.1(45.6-48.6)$ & $27.7(26.0-29.4)$ & $35.8(34.0-37.7)$ & $72.3(70.6-74.0)$ \\
\hline \multicolumn{6}{|c|}{ Exposure to cigarette or other tobacco product marketing ${ }^{\dagger+t}$} \\
\hline Overall & $72.8(71.3-74.3)$ & $43.1(41.4-44.7)$ & $26.8(25.0-28.6)$ & $36.7(34.9-38.6)$ & $81.7(80.7-82.7)$ \\
\hline Estimated no. & $18,670,000$ & $11,180,000$ & $6,770,000$ & $5,410,000$ & $21,630,000$ \\
\hline \multicolumn{6}{|l|}{ Sex } \\
\hline Male & $70.8(68.8-72.8)$ & $40.6(38.2-43.1)$ & $24.8(22.6-27.1)$ & $36.9(34.1-39.8)$ & $79.5(78.0-81.0)$ \\
\hline Female & $75.0(73.4-76.5)$ & $45.6(44.0-47.3)$ & $28.8(27.0-30.6)$ & $36.4(34.6-38.3)$ & $84.1(82.9-85.2)$ \\
\hline \multicolumn{6}{|l|}{ Race/Ethnicity } \\
\hline White, non-Hispanic & $77.1(75.6-78.5)$ & $41.7(39.6-43.9)$ & $24.3(22.2-26.5)$ & $36.0(33.7-38.4)$ & 83.7 (82.5-84.9) \\
\hline Black, non-Hispanic & $67.9(65.2-70.4)$ & $48.7(46.2-51.2)$ & $37.0(34.0-40.2)$ & $41.7(37.1-46.4)$ & $82.1(80.1-83.9)$ \\
\hline Hispanic & $69.2(66.8-71.5)$ & $44.2(42.4-46.0)$ & $27.7(25.8-29.7)$ & $36.9(35.1-38.7)$ & $79.7(78.1-81.3)$ \\
\hline Other, non-Hispanic & $61.1(57.7-64.5)$ & $38.8(35.3-42.3)$ & $21.2(18.6-24.1)$ & $30.3(26.7-34.2)$ & $72.9(70.2-75.5)$ \\
\hline \multicolumn{6}{|l|}{ School level } \\
\hline Middle school & $71.7(69.7-73.5)$ & $44.5(42.8-46.2)$ & $25.9(24.0-28.0)$ & $36.8(34.8-38.8)$ & $81.5(80.1-82.8)$ \\
\hline High school & $73.9(72.1-75.6)$ & $42.0(39.8-44.2)$ & $27.5(25.4-29.7)$ & $36.7(34.4-39.1)$ & $82.0(80.7-83.3)$ \\
\hline
\end{tabular}

See table footnotes on the next page. 
TABLE 7. (Continued) Percentage of middle and high school students who reported exposure* to sources of tobacco product marketing (advertisements or promotions), by school level, sex, and race/ethnicity - National Youth Tobacco Survey, United States, 2019

\footnotetext{
Abbreviations: $\mathrm{Cl}=$ confidence interval; e-cigarettes = electronic cigarettes; TV = television.

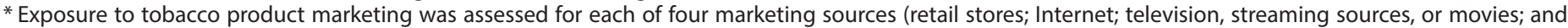

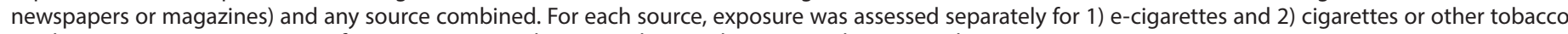
products. A composite measure of exposure to any tobacco product marketing was also assessed.

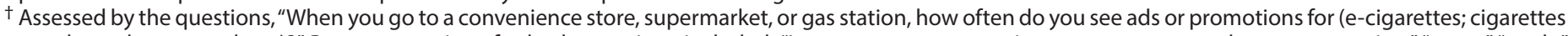

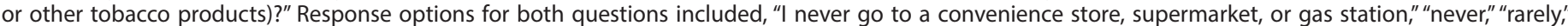

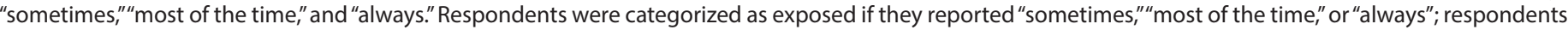

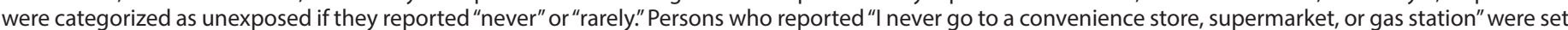

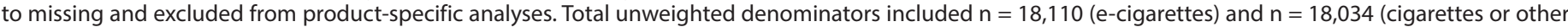

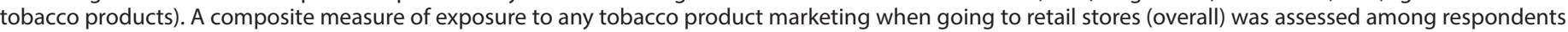
categorized as exposed for at least one measure or unexposed across both measures $(n=18,072)$.

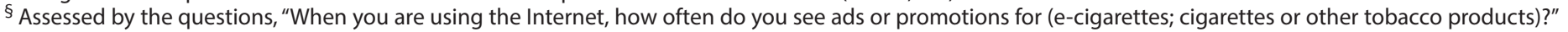

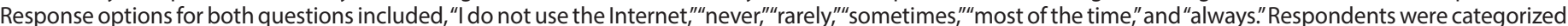

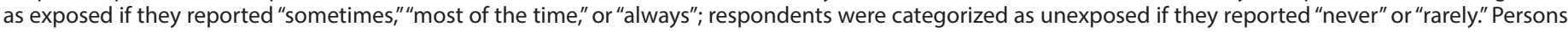

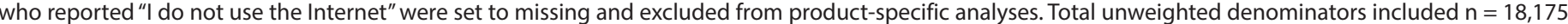

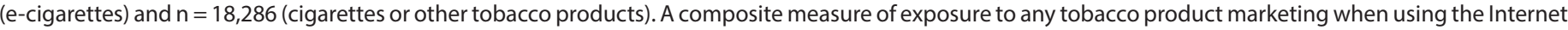
(overall) was assessed among respondents categorized as exposed to marketing for at least one measure or unexposed across both measures ( $\mathrm{n}=18,173$ ).

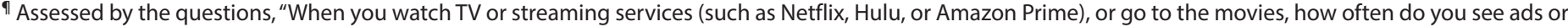

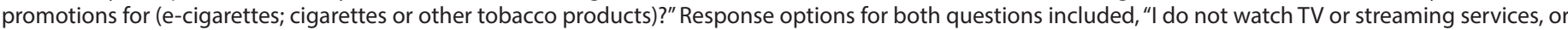

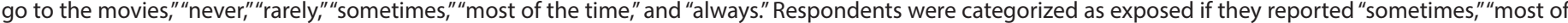

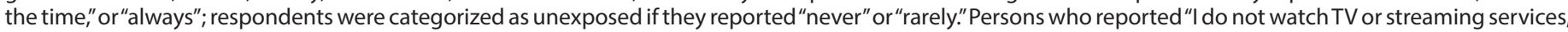

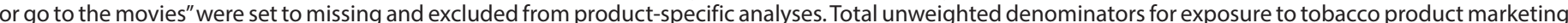

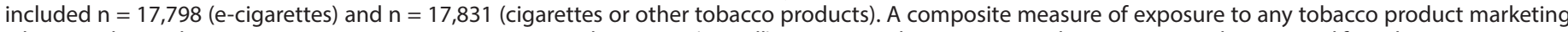

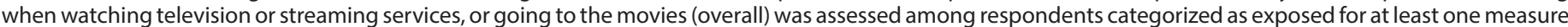
or unexposed across both measures $(n=17,644)$.

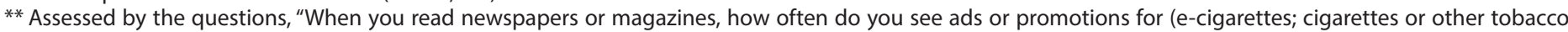

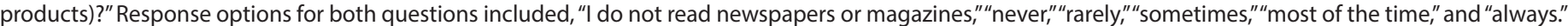

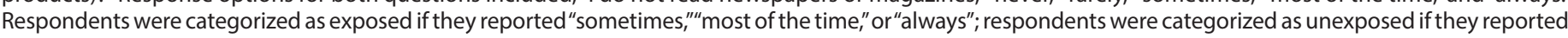

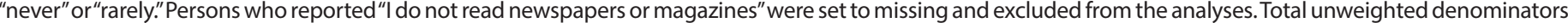

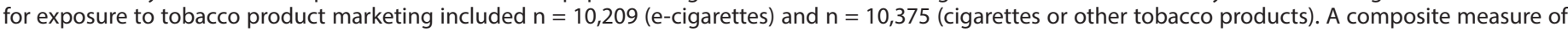

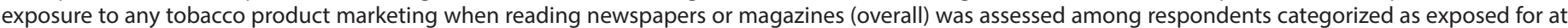
least one measure or unexposed across both measures $(n=9,835)$.

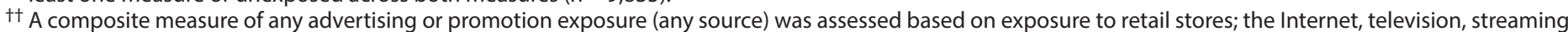

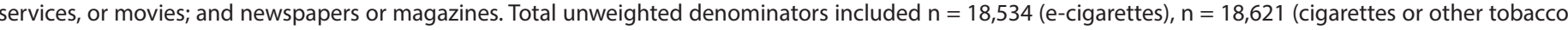
products), and $n=18,695$ (overall)

$\S \S$ Estimated weighted total number of users was rounded down to the nearest 10,000 persons.

११ी Hispanic persons could be of any race.

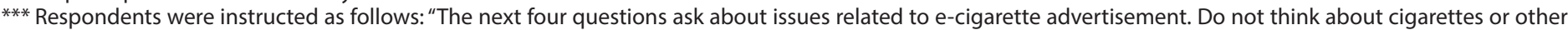
tobacco products."

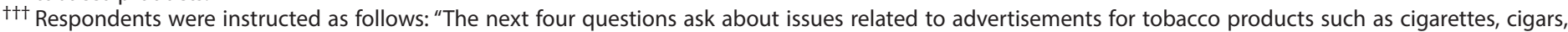
smokeless tobacco, hookahs, roll-your-own cigarettes, pipes, snus, dissolvable tobacco, and bidis. Do not think of electronic cigarettes."
} 
TABLE 8. Curiosity* about and susceptibility ${ }^{\dagger}$ to tobacco product use among never users of each specific product, by school level, sex, and race/ethnicity - National Youth Tobacco Survey, United States, 2019

\begin{tabular}{|c|c|c|c|c|}
\hline \multirow[b]{2}{*}{ Characteristic } & \multicolumn{2}{|c|}{ Curiosity } & \multicolumn{2}{|c|}{ Susceptibility } \\
\hline & $\%(95 \% \mathrm{Cl})$ & Estimated no. ${ }^{\S}$ & $\%(95 \% \mathrm{Cl})$ & Estimated no. \\
\hline $\begin{array}{l}\text { E-cigarettes } \\
\text { Overall }\end{array}$ & $39.1(37.7-40.4)$ & $6,820,000$ & $45.0(43.6-46.5)$ & $7,820,000$ \\
\hline $\begin{array}{l}\text { Sex } \\
\text { Male } \\
\text { Female }\end{array}$ & $\begin{array}{l}37.3(35.8-38.8) \\
41.1(39.2-43.0)\end{array}$ & $\begin{array}{l}3,330,000 \\
3,450,000\end{array}$ & $\begin{array}{l}43.4(41.7-45.1) \\
46.9(44.9-48.8)\end{array}$ & $\begin{array}{l}3,850,000 \\
3,930,000\end{array}$ \\
\hline $\begin{array}{l}\text { Race/Ethnicity } \\
\text { White, non-Hispanic } \\
\text { Black, non-Hispanic } \\
\text { Hispanic" } \\
\text { Other, non-Hispanic }\end{array}$ & $\begin{array}{l}39.8(38.1-41.5) \\
32.0(28.9-35.1) \\
42.3(40.5-44.2) \\
39.8(35.4-44.4)\end{array}$ & $\begin{array}{r}3,630,000 \\
810,000 \\
1,790,000 \\
430,000\end{array}$ & $\begin{array}{l}45.2(43.4-46.9) \\
38.3(34.8-41.8) \\
49.1(46.9-51.3) \\
46.2(41.7-50.7)\end{array}$ & $\begin{array}{r}4,110,000 \\
960,000 \\
2,060,000 \\
500,000\end{array}$ \\
\hline $\begin{array}{l}\text { School level } \\
\text { Middle school } \\
\text { High school }\end{array}$ & $\begin{array}{l}40.6(38.9-42.4) \\
37.2(34.9-39.6)\end{array}$ & $\begin{array}{l}3,840,000 \\
2,950,000\end{array}$ & $\begin{array}{l}47.0(45.1-48.9) \\
42.8(40.6-44.9)\end{array}$ & $\begin{array}{l}4,420,000 \\
3,370,000\end{array}$ \\
\hline $\begin{array}{l}\text { Cigarettes } \\
\text { Overall }\end{array}$ & $37.0(35.8-38.2)$ & $8,320,000$ & $45.9(44.6-47.3)$ & $10,330,000$ \\
\hline $\begin{array}{l}\text { Sex } \\
\text { Male } \\
\text { Female }\end{array}$ & $\begin{array}{l}36.8(35.5-38.2) \\
37.2(35.4-39.0)\end{array}$ & $\begin{array}{l}4,180,000 \\
4,090,000\end{array}$ & $\begin{array}{l}46.4(44.8-47.9) \\
45.5(43.7-47.4)\end{array}$ & $\begin{array}{l}5,260,000 \\
5,010,000\end{array}$ \\
\hline $\begin{array}{l}\text { Race/Ethnicity } \\
\text { White, non-Hispanic } \\
\text { Black, non-Hispanic } \\
\text { Hispanic } \\
\text { Other, non-Hispanic }\end{array}$ & $\begin{array}{l}37.2(35.8-38.6) \\
29.8(26.4-33.3) \\
40.5(38.4-42.7) \\
38.4(33.9-43.1)\end{array}$ & $\begin{array}{r}4,490,000 \\
910,000 \\
2,240,000 \\
500,000\end{array}$ & $\begin{array}{l}45.7(44.2-47.3) \\
38.4(34.1-42.9) \\
50.5(48.3-52.8) \\
46.1(41.4-50.8)\end{array}$ & $\begin{array}{r}5,520,000 \\
1,180,000 \\
2,780,000 \\
600,000\end{array}$ \\
\hline $\begin{array}{l}\text { School level } \\
\text { Middle school } \\
\text { High school }\end{array}$ & $\begin{array}{l}39.9(38.5-41.3) \\
34.3(32.3-36.4)\end{array}$ & $\begin{array}{l}4,310,000 \\
3,980,000\end{array}$ & $\begin{array}{l}49.5(47.7-51.3) \\
42.7(40.6-44.8)\end{array}$ & $\begin{array}{l}5,350,000 \\
4,950,000\end{array}$ \\
\hline $\begin{array}{l}\text { Cigars } \\
\text { Overall }\end{array}$ & $28.0(27.0-28.9)$ & $6,440,000$ & $35.9(34.9-37.0)$ & $8,250,000$ \\
\hline $\begin{array}{l}\text { Sex } \\
\text { Male } \\
\text { Female }\end{array}$ & $\begin{array}{l}31.1(29.8-32.4) \\
24.8(23.7-25.9)\end{array}$ & $\begin{array}{l}3,590,000 \\
2,810,000\end{array}$ & $\begin{array}{l}38.9(37.6-40.3) \\
32.8(31.6-34.1)\end{array}$ & $\begin{array}{l}4,480,000 \\
3,710,000\end{array}$ \\
\hline $\begin{array}{l}\text { Race/Ethnicity } \\
\text { White, non-Hispanic } \\
\text { Black, non-Hispanic } \\
\text { Hispanic } \\
\text { Other, non-Hispanic }\end{array}$ & $\begin{array}{l}27.0(25.8-28.4) \\
26.0(23.9-28.3) \\
31.6(29.7-33.5) \\
27.4(24.2-30.9)\end{array}$ & $\begin{array}{r}3,410,000 \\
740,000 \\
1,790,000 \\
360,000\end{array}$ & $\begin{array}{l}34.6(33.2-36.1) \\
34.1(31.6-36.8) \\
40.8(38.6-43.0) \\
32.9(29.6-36.4)\end{array}$ & $\begin{array}{r}4,350,000 \\
980,000 \\
2,300,000 \\
440,000\end{array}$ \\
\hline $\begin{array}{l}\text { School level } \\
\text { Middle school } \\
\text { High school }\end{array}$ & $\begin{array}{l}26.5(25.3-27.7) \\
29.3(27.9-30.7)\end{array}$ & $\begin{array}{l}2,930,000 \\
3,480,000\end{array}$ & $\begin{array}{l}34.6(33.1-36.1) \\
37.2(35.7-38.7)\end{array}$ & $\begin{array}{l}3,810,000 \\
4,400,000\end{array}$ \\
\hline
\end{tabular}

See table footnotes on the next page. 
TABLE 8. (Continued) Curiosity* about and susceptibility ${ }^{\dagger}$ to tobacco product use among never users of each specific product, by school level, sex, and race/ethnicity - National Youth Tobacco Survey, United States, 2019

\begin{tabular}{|c|c|c|c|c|}
\hline \multirow[b]{2}{*}{ Characteristic } & \multicolumn{2}{|c|}{ Curiosity } & \multicolumn{2}{|c|}{ Susceptibility } \\
\hline & $\%(95 \% \mathrm{Cl})$ & Estimated no. $\$$ & $\%(95 \% \mathrm{Cl})$ & Estimated no. \\
\hline \multicolumn{5}{|c|}{ Smokeless tobacco products } \\
\hline Overall & $15.9(14.7-17.1)$ & $3,950,000$ & $21.2(19.7-22.8)$ & $5,230,000$ \\
\hline \multicolumn{5}{|l|}{ Sex } \\
\hline Male & $18.7(16.9-20.6)$ & $2,300,000$ & $24.6(22.2-27.3)$ & $3,010,000$ \\
\hline Female & $13.1(12.0-14.3)$ & $1,620,000$ & $17.7(16.5-19.1)$ & $2,180,000$ \\
\hline \multicolumn{5}{|l|}{ Race/Ethnicity } \\
\hline White, non-Hispanic & $16.8(15.4-18.3)$ & $2,220,000$ & 21.7 (19.9-23.6) & $2,860,000$ \\
\hline Black, non-Hispanic & $9.8(8.3-11.6)$ & 330,000 & $14.4(12.3-16.7)$ & 480,000 \\
\hline Hispanic & $16.6(15.0-18.3)$ & $1,040,000$ & $23.0(21.0-25.1)$ & $1,420,000$ \\
\hline Other, non-Hispanic & $17.5(14.3-21.2)$ & 240,000 & $22.3(18.6-26.5)$ & 300,000 \\
\hline \multicolumn{5}{|l|}{ School level } \\
\hline Middle school & $19.2(17.8-20.7)$ & $2,180,000$ & $25.7(23.9-27.6)$ & $2,900,000$ \\
\hline High school & $13.1(11.6-14.7)$ & $1,750,000$ & $17.3(15.6-19.2)$ & $2,300,000$ \\
\hline \multicolumn{5}{|l|}{ Hookahs } \\
\hline Overall & $23.2(22.2-24.2)$ & $5,790,000$ & $29.9(28.9-31.0)$ & $7,390,000$ \\
\hline \multicolumn{5}{|l|}{ Sex } \\
\hline Male & $21.6(20.2-23.0)$ & $2,780,000$ & $28.5(27.0-30.0)$ & $3,620,000$ \\
\hline Female & $25.0(23.7-26.4)$ & $2,990,000$ & $31.5(30.0-33.0)$ & $3,730,000$ \\
\hline \multicolumn{5}{|l|}{ Race/Ethnicity } \\
\hline White, non-Hispanic & $21.7(20.5-23.1)$ & $3,020,000$ & $27.9(26.5-29.3)$ & $3,860,000$ \\
\hline Black, non-Hispanic & $22.4(20.3-24.6)$ & 700,000 & $30.1(28.1-32.3)$ & 920,000 \\
\hline Hispanic & $28.1(26.3-30.0)$ & $1,670,000$ & $35.5(33.5-37.6)$ & $2,100,000$ \\
\hline Other, non-Hispanic & $20.7(18.1-23.6)$ & 280,000 & $25.9(23.0-29.0)$ & 340,000 \\
\hline \multicolumn{5}{|l|}{ School level } \\
\hline Middle school & $18.8(17.5-20.1)$ & $2,130,000$ & $25.2(23.7-26.8)$ & $2,840,000$ \\
\hline High school & $26.9(25.5-28.4)$ & $3,630,000$ & $33.8(32.3-35.4)$ & $4,520,000$ \\
\hline
\end{tabular}

Abbreviations: $\mathrm{Cl}$ = confidence interval; e-cigarettes = electronic cigarettes.

* Assessed by the question, "Have you ever been curious about (tobacco product)?" Responses were recoded as highly curious (definitely yes, probably yes, or probably not) and not curious (definitely not). Overall estimates of curiosity were calculated among never tobacco product users of the specific tobacco product: e-cigarettes $(n=12,523)$, cigarettes $(n=16,031)$, cigars $(n=16,411)$, smokeless tobacco (chewing tobacco, snuff, and dip; $n=17,664)$, and hookahs $(n=17,627)$.

${ }^{\dagger}$ Assessed by the questions, "Do you think that you will use (tobacco product) soon? Do you think you will use (tobacco product) in the next year? If one of your best friends were to offer you (tobacco product), would you try it? Have you ever been curious about (tobacco product)?" Susceptibility was defined as a response other than "definitely not" to any of the four questions. Respondents with a missing value for all four questions or any combination of "definitely not" and missing value or values were recoded as missing for susceptibility. Overall estimates of susceptibility were calculated among never tobacco product users of the specific tobacco product: e-cigarettes $(n=12,448)$, cigarettes $(n=16,010)$, cigars $(n=16,347)$, smokeless tobacco (chewing tobacco, snuff, and dip; $n=17,513)$, and hookahs $(n=17,549)$.

$\S$ Estimated weighted total numbers were rounded down to the nearest 10,000 persons. Overall estimates might not directly total to sums of corresponding subgroup estimates because of rounding or inclusion of students who did not self-report sex, race/ethnicity, or grade level.

" Hispanic persons could be of any race. 
TABLE 9. Urges to use tobacco products and quitting behaviors among middle and high school students who reported current tobacco product use, ${ }^{*}$ by school level, sex, and race/ethnicity — National Youth Tobacco Survey, United States, 2019

\begin{tabular}{|c|c|c|c|c|c|c|c|c|}
\hline \multirow[b]{3}{*}{ Characteristic } & \multicolumn{4}{|c|}{ Urges to use tobacco products } & \multicolumn{4}{|c|}{ Quitting behaviors } \\
\hline & \multicolumn{2}{|c|}{ Past 30-day craving ${ }^{\dagger}$} & \multicolumn{2}{|c|}{ Within 30 minutes of waking ${ }^{\S}$} & \multicolumn{2}{|c|}{ Thinking about quitting? } & \multicolumn{2}{|c|}{ Past-year quit attempt** } \\
\hline & $\%(95 \% \mathrm{Cl})$ & $\begin{array}{c}\text { Estimated } \\
\text { no. }{ }^{\dagger \dagger}\end{array}$ & $\%(95 \% \mathrm{Cl})$ & $\begin{array}{c}\text { Estimated } \\
\text { no. }\end{array}$ & $\%(95 \% \mathrm{Cl})$ & $\begin{array}{c}\text { Estimated } \\
\text { no. }\end{array}$ & $\%(95 \% \mathrm{Cl})$ & $\begin{array}{c}\text { Estimated } \\
\text { no. }\end{array}$ \\
\hline Overall & $24.7(22.0-27.6)$ & $1,510,000$ & $13.7(11.7-16.0)$ & 830,000 & $57.8(55.5-60.0)$ & $3,330,000$ & $57.5(55.4-59.6)$ & $3,300,000$ \\
\hline $\begin{array}{l}\text { Sex } \\
\text { Male } \\
\text { Female }\end{array}$ & $\begin{array}{l}23.8(19.9-28.1) \\
25.8(22.9-28.9)\end{array}$ & $\begin{array}{l}760,000 \\
740,000\end{array}$ & $\begin{array}{r}15.7(12.7-19.4) \\
11.5(9.5-13.9)\end{array}$ & $\begin{array}{l}500,000 \\
330,000\end{array}$ & $\begin{array}{l}56.8(54.2-59.2) \\
58.9(55.6-62.1)\end{array}$ & $\begin{array}{l}1,740,000 \\
1,580,000\end{array}$ & $\begin{array}{l}57.0(54.3-59.6) \\
58.0(55.0-61.0)\end{array}$ & $\begin{array}{l}1,730,000 \\
1,560,000\end{array}$ \\
\hline $\begin{array}{l}\text { Race/Ethnicity } \\
\text { White, non-Hispanic } \\
\text { Black, non-Hispanic } \\
\text { Hispanic } \\
\text { Other, non-Hispanic }\end{array}$ & $\begin{array}{r}28.7(25.5-32.1) \\
15.8(12.0-20.6) \\
18.3(15.1-21.9) \\
-\end{array}$ & $\begin{array}{r}1,070,000 \\
100,000 \\
250,000 \\
-\end{array}$ & $\begin{array}{c}16.5(13.9-19.5) \\
{ }^{\S \S} \\
9.2(7.2-11.6) \\
-\end{array}$ & $\begin{array}{r}610,000 \\
- \\
120,000 \\
-\end{array}$ & $\begin{array}{l}56.2(54.2-58.9) \\
59.5(53.8-65.0) \\
61.6(58.0-65.0) \\
56.7(45.8-67.1)\end{array}$ & $\begin{array}{r}1,990,000 \\
370,000 \\
810,000 \\
120,000\end{array}$ & $\begin{array}{l}55.3(52.4-58.2) \\
59.1(53.3-64.6) \\
62.9(59.0-66.7) \\
56.9(48.6-64.9)\end{array}$ & $\begin{array}{r}1,950,000 \\
360,000 \\
820,000 \\
120,000\end{array}$ \\
\hline High school & $25.8(22.6-29.4)$ & $1,200,000$ & $15.6(13.2-18.4)$ & 720,000 & $57.7(55.3-60.0)$ & $2,540,000$ & $55.7(53.2-58.2)$ & $2,440,000$ \\
\hline $\begin{array}{l}\text { Sex } \\
\text { Male } \\
\text { Female }\end{array}$ & $\begin{array}{l}25.5(21.1-30.5) \\
26.3(22.9-30.0)\end{array}$ & $\begin{array}{l}630,000 \\
560,000\end{array}$ & $\begin{array}{l}18.0(14.4-22.2) \\
13.0(10.7-15.8)\end{array}$ & $\begin{array}{l}440,000 \\
280,000\end{array}$ & $\begin{array}{l}57.2(54.3-60.0) \\
58.2(54.8-61.5)\end{array}$ & $\begin{array}{l}1,350,000 \\
1,180,000\end{array}$ & $\begin{array}{l}56.0(53.1-58.9) \\
55.3(51.7-58.8)\end{array}$ & $\begin{array}{l}1,310,000 \\
1,120,000\end{array}$ \\
\hline $\begin{array}{l}\text { Race/Ethnicity } \\
\text { White, non-Hispanic } \\
\text { Black, non-Hispanic } \\
\text { Hispanic } \\
\text { Other, non-Hispanic }\end{array}$ & $\begin{array}{r}29.9(26.2-33.8) \\
16.1(11.7-21.8) \\
17.4(14.0-21.4) \\
-\end{array}$ & $\begin{array}{r}900,000 \\
70,000 \\
160,000 \\
-\end{array}$ & $\begin{array}{r}18.7(15.8-22.1) \\
- \\
9.4(6.8-12.9) \\
-\end{array}$ & $\begin{array}{r}560,000 \\
- \\
80,000 \\
-\end{array}$ & $\begin{array}{l}56.2(53.1-59.3) \\
61.2(56.1-66.2) \\
61.6(57.2-65.7) \\
52.7(41.6-63.5)\end{array}$ & $\begin{array}{r}1,620,000 \\
280,000 \\
530,000 \\
80,000\end{array}$ & $\begin{array}{l}53.8(50.4-57.1) \\
58.7(52.4-64.6) \\
60.3(55.2-65.1) \\
56.8(48.3-64.9)\end{array}$ & $\begin{array}{r}1,540,000 \\
260,000 \\
520,000 \\
90,000\end{array}$ \\
\hline Middle school & $21.4(18.1-25.1)$ & 310,000 & $7.3(5.8-9.2)$ & 100,000 & $57.9(52.3-63.4)$ & 770,000 & $63.3(59.3-67.1)$ & 840,000 \\
\hline $\begin{array}{l}\text { Sex } \\
\text { Male } \\
\text { Female }\end{array}$ & $\begin{array}{l}18.2(14.7-22.4) \\
24.6(19.4-30.8)\end{array}$ & $\begin{array}{l}130,000 \\
170,000\end{array}$ & - & - & $\begin{array}{l}54.9(48.3-61.5) \\
61.0(54.3-67.3)\end{array}$ & $\begin{array}{l}370,000 \\
390,000\end{array}$ & $\begin{array}{l}59.6(53.6-65.4) \\
66.7(61.4-71.5)\end{array}$ & $\begin{array}{l}400,000 \\
430,000\end{array}$ \\
\hline $\begin{array}{l}\text { Race/Ethnicity } \\
\text { White, non-Hispanic } \\
\text { Black, non-Hispanic } \\
\text { Hispanic } \\
\text { Other, non-Hispanic }\end{array}$ & $\begin{array}{r}23.7(18.5-29.9) \\
20.3(15.7-25.8) \\
-\end{array}$ & $\begin{array}{r}160,000 \\
- \\
90,000 \\
-\end{array}$ & $\begin{array}{l}- \\
- \\
-\end{array}$ & $\begin{array}{l}- \\
- \\
-\end{array}$ & $\begin{array}{r}55.8(49.3-62.1) \\
54.6(41.4-67.2) \\
61.7(54.9-68.0) \\
-\end{array}$ & $\begin{array}{r}360,000 \\
90,000 \\
260,000 \\
-\end{array}$ & $\begin{array}{r}62.4(54.7-69.5) \\
60.3(51.5-68.5) \\
67.6(61.7-72.9) \\
-\end{array}$ & $\begin{array}{r}410,000 \\
90,000 \\
280,000 \\
-\end{array}$ \\
\hline
\end{tabular}

Abbreviation: $\mathrm{Cl}=$ confidence interval.

* Any current tobacco product use was defined as use of any tobacco product (e-cigarettes, cigarettes, cigars, smokeless tobacco, hookahs, pipe tobacco, or bidis [small brown cigarettes wrapped in a leaf]) on $\geq 1$ day during the past 30 days $(n=4,198)$.

† Assessed by the question,"During the past 30 days, have you had a strong craving or felt like you really needed to use a tobacco product of any kind?"The response options were yes or no.

$\S$ Assessed by the question, "How soon after you wake up do you want to use a tobacco product?" Response options were dichotomized as within 30 minutes (within 5 minutes or from 6 to 30 minutes) or not within 30 minutes (from more than 30 minutes to 1 hour, after $>1$ hour but $<24$ hours, "I rarely want to use tobacco products," or "I do not want to use tobacco products").

ף Assessed by the question, "Are you seriously thinking about quitting the use of all tobacco products?" Response options were dichotomized as yes ("yes, during the next 30 days"; "yes, during the next 6 months"; "yes, during the next 12 months"; or "yes, but not during the next 12 months") or no ("no, I am not thinking about quitting the use of all tobacco products").

** Assessed by the question, "During the past 12 months, how many times have you stopped using all tobacco products for one day or longer because you were trying to quit all tobacco products for good?" Response options were dichotomized as yes (one time, two times, three to five times, six to nine times, or $\geq 10$ times) or no ("no, I did not try to quit during the past 12 months").

${ }^{+\dagger}$ Estimated weighted total numbers of users were rounded down to the nearest 10,000 persons. Overall estimates might not directly total to sums of corresponding subgroup estimates because of rounding or inclusion of students who did not self-report sex, race/ethnicity, or grade level.

$\S \S$ Data were statistically unreliable because of unweighted denominator $<50$ or a relative standard error $>30 \%$.

१ी Hispanic persons could be of any race. 



The Morbidity and Mortality Weekly Report (MMWR) Series is prepared by the Centers for Disease Control and Prevention (CDC) and is available free of charge in electronic format. To receive an electronic copy each week, visit MMWR at https://www.cdc.gov/mmwr/index.html.

Readers who have difficulty accessing this PDF file may access the HTML file at https://www.cdc.gov/mmwr/volumes/68/ss/ss6812a1.htm?s_ cid=ss6812a1_w. Address all inquiries about the $M M W R$ Series, including material to be considered for publication, to Executive Editor, $M M W R$ Series, Mailstop E-90, CDC, 1600 Clifton Rd., N.E., Atlanta, GA 30329-4027 or to mmwrq@cdc.gov.

All material in the MMWR Series is in the public domain and may be used and reprinted without permission; citation as to source, however, is appreciated. MMWR and Morbidity and Mortality Weekly Report are service marks of the U.S. Department of Health and Human Services.

Use of trade names and commercial sources is for identification only and does not imply endorsement by the U.S. Department of Health and Human Services.

References to non-CDC sites on the Internet are provided as a service to $M M W R$ readers and do not constitute or imply endorsement of these organizations or their programs by CDC or the U.S. Department of Health and Human Services. CDC is not responsible for the content of these sites. URL addresses listed in $M M W R$ were current as of the date of publication.

ISSN: 0149-2195 (Print) 